\title{
INTEGRAÇÃO ENSINO SERVIÇO E PRÁTICAS DE APOIO INSTITUCIONAL NA FORMAÇÃO DO FONOAUDIÓLOGO ${ }^{60}$
}

\section{TEACHING AND SERVICE INTEGRATION AND INSTITUTIONAL SUPPORT PRACTICES IN SPEECH PATHOLOGIST FORMATION}

\section{Resumo}

Reflexões sobre a formação dos profissionais de saúde mostram a necessidade de haver uma prática profissional integrada com o sistema de saúde, buscando compreender como as ações de apoio institucional utilizados em diferentes cenários do estágio (saúde coletiva) de um curso de graduação em fonoaudiologia contribuem para construção da clínica fonoaudiológica orientada pelos princípios do SUS. Realizou-se um grupo focal com formandos correlacionando as vivências do estágio com os temas acolhimento, formação em saúde, apoio institucional e processo de trabalho. Os achados foram analisados pela perspectiva da análise temática, apresentando impacto significativo na formação e construção da identidade profissional a partir da imersão em práticas cuidadoras em saúde com foco no sujeito integral.

Palavras-chave: Formação em Saúde. Atenção Básica em Saúde. Apoio Institucional. Comunicação em Saúde. Fonoaudiologia.

\begin{abstract}
Reflections on the training of health professionals demonstrate the need for a professional practice integrated with the health system aim to understand how the institutional support practices used in different scenarios of the internship (collective health) of an undergraduate speech therapy course contribute to the construction of clinical speech therapy practice. A focus group with graduates was conducted to correlate the internship practices with the themes of reception, health training, institutional support and work process. The findings were analyzed from the perspective of thematic analysis and as resulted on the significantly impact on their formation and on the construction of their professional identity through immersion in health care practices with focus on integral person.
\end{abstract}

Keywords: Health formation. Basics health care. Institutional support. Health communication. Speech therapy.

\footnotetext{
60 Este texto resulta da Dissertação de Mestrado realizado no MPES/UFF.

61 Fonoaudióloga, mestranda da Universidade Federal Fluminense. Escola de Enfermagem Aurora de Afonso Costa. Programa de Mestrado Profissional em Ensino na Saúde: Formação docente interdisciplinar para o SUS Niterói, RJ-Brasil. Email: marianacabral.fono@yahoo.com.br. ORCID: https://orcid.org/0000-0001-8731-6857

62 Professor Associado III - Universidade Federal Fluminense. Instituto de Saúde de Nova Friburgo. Departamento de Formação Específica em Fonoaudiologia - Nova Friburgo, RJ- Brasil.Email: gilsonsaippa@gmail.com .ORCID: https://orcid.org/0000-0001-8677-096X

63 Psicólogo, Servidor da Secretaria Municipal de Saúde do Município de Nova Friburgo- RJ, Mestrando da Universidade Federal Fluminense. Escola de Enfermagem Aurora de Afonso Costa. Programa de Mestrado Profissional em Ensino na Saúde: Formação docente interdisciplinar para o SUS - Niterói- RJ. Email:leonesoliveiraleo@gmail.com . ORCID: https://orcid.org/0000-0003-2933-228X
} 


\section{Introdução}

A discussão de uma nova proposta de formação acadêmica aos profissionais da saúde, impulsionados por movimentos que articulam ensino-serviço-comunidade, se estende a formação dos fonoaudiólogos, evidenciada pelas Diretrizes Curriculares Nacionais (DCNs) para os Cursos de Fonoaudiologia ao definirem o Sistema de Saúde (SUS) como eixo orientador das práticas em saúde. Esse documento coloca o usuário no centro da atenção, considera a pluralidade e a singularidade do processo de viver, evidenciados a partir de experiências e aprendizagem capazes de repensar aspectos do processo de trabalho, da gestão e do planejamento (PINHEIRO et al, 2014);(OLIVEIRA; CAMPOS, 2017).

A construção de espaços e momentos pedagógicos, orientados por práticas de apoio, que valorizem ao longo da formação dos profissionais de saúde a transformação dos sujeitos e da comunidade em cuidadores de sua própria saúde, com base na busca permanente da integralidade e equidades das ações se transforma, portanto, num importante dispositivo da formação em saúde (SAIPPA OLIVEIRA; KOIFMAN; PINHEIRO, 2006).

Faz-se necessário, portanto, que o processo formativo do fonoaudiólogo acompanhe estes desafios e que sua formação seja ampliada, com foco sobre o cuidado do indivíduo, não só na sua dimensão anatomofisiopatológica e na reabilitação, mas a partir da integralidade do cuidado, universalidade de acesso e equidade, de acordo com princípios e diretrizes do SUS, de forma que esses aspectos sejam incorporados no processo formativo e posteriormente sejam levados em consideração no momento da atuação profissional (AYRES, 2007);(RODRIGUES, 2014).

Este artigo busca compreender como as vivências de graduandos de fonoaudiologia em cenários de experimentação de práticas de apoio institucional impactam na construção da identidade profissional.

\section{Referencial Teórico}

As atuais propostas de reestruturação das práticas de saúde têm dado destaque ao conceito de humanização, preconizando o atendimento integral e acesso à saúde (AYRES, 2005). A partir do entendimento da importância da humanização nas políticas de saúde, é 


\section{RevistAleph}

necessário revisitar seus conceitos para se realizar mudanças no modelo de atenção e de gestão diante da banalização do tema e da fragmentação das práticas em saúde (BENEVIDES; PASSOS, 2005).

Nesta direção a Política Nacional de Humanização (PNH) orientada por um conjunto de princípios e diretrizes baseia-se nos princípios de inseparabilidade da atenção e gestão, e transversalidade, gerando mudanças na prática de saúde e nos modelos de atenção e gestão, pautados no modelo biomédico predominante. Suas contribuições têm características próprias, visto que seu intuito tem sido de mudanças no processo de trabalho no campo da saúde (SANTOS FILHO; BARROS; GOMES, 2009).

Tais diretrizes trazem orientações para o trabalho na produção de saúde, que conectam usuários, trabalhadores e gestores através de práticas clínicas diferenciadas, reforça a valorização dos atores implicados na produção do cuidado, a autonomia e protagonismo do usuário, responsabilização pela atenção e melhoria das condições de trabalho, produzindo um debate sobre questões éticas do cuidado, comunicação e projetos terapêuticos que se comprometam com o usuário e seus direitos, sendo elas: acolhimento, gestão democrática, clinica ampliada, valorização do trabalho e garantia de direitos dos usuários (DESLANDES; MITRE, 2009); (SANTOS FILHO; BARROS; GOMES, 2009); (PASCHE, 2010).

O acolhimento, a escuta, as trocas e interpretações de encontros, assim como as aprendizagens e experiências do outro, são considerados tecnologias envolvidas no cuidado, e podem fortalecer a instituição de novas formas de produzir cuidado, criando uma racionalidade comunicativa (DESLANDES; MITRE, 2009).

Desta forma, é possível analisar o processo de trabalho em saúde, em que as relações geram mudança na forma de atuação dos profissionais, sendo fundamental a articulação das práticas em saúde com as diretrizes, na tentativa de ampliá-las na busca pela reorganização dos serviços e práticas que promovam saúde e qualidade de vida aos seus usuários. Confirma que é fundamental o repensar da atuação, os encontros e espaços coletivos, e seu papel transformador na atuação (RIBEIRO, 2012).

As concepções de acolhimento ganham corpo no cotidiano das práticas através da escuta qualificada e da possibilidade de estabelecer relações entre demanda e resposta da assistência. A qualidade do cuidado vem da responsabilização mesmo quando não é possível 


\section{RevistAleph}

resolver de imediato, mas que seu direcionamento seja realizado de forma ética e segura para o usuário. Diante disso, a mudança no processo de trabalho e gestão, proposta pelo acolhimento, é um recurso fundamental para a humanização das práticas em saúde (BRASIL, 2008).

Vê-se a necessidade de discutir o apoio, entendido aqui enquanto dispositivo relacional do método Paidéia, metodologia que aposta na capacidade de análise e cogestão dos profissionais envolvidos, que tem sido usado em diferentes níveis de ensino, em que são combinadas discussões de casos, reflexões sobre a prática e materiais teóricos, trazendo em suas vivências, pautadas no apoio, o "aprender fazendo" que se destaca como principal ferramenta para formação de apoiadores (OLIVEIRA; CAMPOS, 2017).

Assim, o apoio é tomado como elemento central de produção de corresponsabilizações dos sujeitos nos processos de deliberação e compreensão dos destinos de uma determinada instituição que são capazes de instaurar novos saberes e novas práticas, na direção da criar espaços permanentes de coprodução, negociação de contratos e compromissos sempre provisórios (CAMPOS, 2000), possibilitando a transformação, construindo o conhecimento transdisciplinar nas equipes multiprofissionais (CUNHA; CAMPOS, 2010).

A função apoio assume essa reformulação, acompanha os processos de mudança nas organizações, unindo recursos da análise institucional para pensar a gestão. Trazendo mudanças aos trabalhadores dando-lhes instrumentos para efetivar as transformações no processo de trabalho (BARROS et al., 2014).

Andrade et al. (2014) defendem que inserir apoiadores nos serviços tem sido uma inovação para substituir os modelos assistenciais vigentes, gerando mudanças no processo de trabalho de forma individual ou coletiva.

Figueiredo e Campos (2014), por sua vez, apresentam a concepção de que o apoio tem seu trabalho pautado na quebra de paradigmas do conceito biomédico tecnicista que permeia os cenários de formação, que não viabiliza a qualificação profissional pautadas na complexidade da subjetividade, funcionando no modelo clínico ambulatorial.

Saldanha et al. (2014) acrescentam que criar equipes de apoio nos serviços gera mudança na formação de profissionais, de docentes e estudantes, visto que o apoio busca proporcionar espaços de diálogo compartilhado entre equipe e apoiadores. Dizem também 


\section{RevistAleph}

que esses recursos ainda são poucos ou inexistentes na graduação, como é percebido na realidade da universidade, em que a utilização de estratégias de apoio acontece apenas nos períodos finais da graduação.

Figueiredo e Campos (2014) evidenciam que ao realizar o apoio em espaços coletivos, em que são possibilitados encontros entre os profissionais, de forma a se colocarem em relação e refletirem sobre a prática, com discussões sobre casos reais e temas relevantes, coloca-se em destaque a subjetividade do profissional, ao estabelecer uma relação clínica e de afeto, que favorece a criatividade para resolução a partir da interligação entre o conhecimento e a prática, que dá corpo ao processo ensino-aprendizagem. A valorização desses encontros é vivenciada nas reuniões de equipes em que as discussões são disparadas pelos profissionais e pelos alunos, que ao se colocarem em relação provocam reflexão sobre suas ações.

O apoio institucional traz estratégias pautadas na potencialidade da construção de redes de sujeitos e de serviços, em que o processo de trabalho é o objeto da intervenção do apoiador ao colocar em discussão os sujeitos envolvidos, dando-lhes voz e autonomia para mudanças em suas práticas, ao permitir a problematização do cotidiano ofertando metodologias de análise, planejamento e intervenção clínica. O novo profissional de saúde necessita revisar a forma de trabalho a partir de demandas que implicam em maior autonomia e constante aprendizado, mudanças não apenas técnicas, mas éticas e socioculturais (PAIXÃO; TAVARES, 2014).

Cassela e Machado (2017) entendem que a visão do apoio institucional levou a quebra de paradigmas ao valorizar o trabalho, pois busca mudar processos consolidados que envolvem diversos obstáculos, como hierarquias profissionais, relação interpessoais fragilizadas, setores fragmentados e qualidade da prestação de serviços. Andrade et al. (2014) reforçam que estabelecer uma boa relação entre apoiadores e equipe permite a análise dos processos de trabalho e a efetivação de ações voltadas para os direitos do usuário.

A visão sobre o trabalho do apoiador nem sempre é clara para trabalhadores e gestores, e às vezes nem para os apoiadores, causados muitas vezes pela dificuldade em entender seu território de atuação e a forma de apoio que faz. Essa dificuldade vem do distanciamento da gestão, que não entende o apoiador como integrante da implementação da política, da pouca circulação de fala, que estabelece relações de poder por aquele que tem 


\section{RevistAleph}

como função a problematização nas equipes, demostra insegurança de apoiadores em evidenciar situações da prática, por medo de gerar uma percepção equivocada, que desequilibre a relação com trabalhadores e profissionais, além da compreensão de humanização, que se caracteriza apenas pela cordialidade, sendo de grande importância repensar esse conceito, além das posturas endurecidas e fragmentadas que impedem a humanização das práticas (CASSELA; MACHADO, 2017); (PAIXÃO; TAVARES, 2014).

\section{Apoio e formação: diálogos no processo de integração ensino-serviço}

Ancorados na perspectiva de que as transformações das práticas de cuidado e formação em saúde devem se orientar por uma concepção de gestão que destaca todos os envolvidos, defende-se que ao problematizar o dia a dia e produzir mudanças no processo de trabalho, valoriza-se a autonomia dos espaços coletivos, desvia-se tais práticas do conceito de pura burocratização do serviço, pois ao potencializar o diálogo, a promoção de saúde, diminui-se as situações de adoecimento dos trabalhadores (SILVA; BARROS; MARTINS, 2015).

Costa et al. (2012) e Figueiredo e Campos (2014), nesta mesma direção, percebem que a transformação do trabalho acontece juntamente com os sujeitos e instituições a partir da formação, que se estabelece pela reflexão sobre a prática e suas relações. É necessário interligar a teoria com a prática, a partir de problematização de vivências, habilitando a capacidade de refletir dos sujeitos, e que para haver mudança no processo de trabalho, é preciso que modificações iniciem ainda na formação acadêmica, flexibilizando os modos de fazer.

Furlan e Campos (2014) reforçam essa transformação ao evidenciar que o apoio tem sido usado na rede como um recurso na gestão participativa, no seguimento educacional e como analisador de projetos em andamento nos serviços, visando esse movimento de mudança na forma de trabalhar a partir da autonomia dos sujeitos envolvidos na produção de saúde, manejando aprendizados e pessoas.

Com isso, busca-se a formação de profissionais para o SUS que tenham sensibilidade ao cuidar, garantindo o direito à saúde. Por outro ângulo, observa-se que a forma como os serviços funcionam impactam diretamente na formação, já que são realizados estágios nos serviços. A formação depende do seu caminho, tendo na aprendizagem a reflexão. $\mathrm{O}$ apoio acontece na problematização de casos e temas entre equipes de apoio, trabalhadores, 
gestores e usuários, constituindo redes e estabelecendo integração entre os sujeitos valorizando a singularidade do cuidado (SALDANHA et al., 2014).

Pasche (2006) identifica que as instituições de saúde necessitam de uma nova arquitetura institucional que seja capaz de instaurar novos modos de produção de subjetividades e de circulação de poderes, capazes de fomentar inovação nas práticas de saúde, como forma de alterar o modo de produção e fluxos de poder que tendem a se manter a partir de processos de comunicação entre os pares (chefes com chefes, médicos com médicos, enfermeiros com enfermeiros, e assim por diante), dificultando a emergência de processos instituintes, dessa forma, a organização se reproduz, pois se mantém sustentada sobre linhas de forças que apenas reverberam aquilo que já está instituído.

A superação desta arquitetura instituída pode ser amplamente impulsionada pela construção de espaços colegiados (de gestão e de trabalho) e também da formação, a partir de algum tipo de suporte (interno ou externo) ou apoio que configura-se enquanto elemento central de produção (pedagógica e terapêutica) de corresponsabilizações, deliberação e compreensão dos destinos de uma determinada instituição (OLIVEIRA; CAMPOS, 2015).

A consolidação, no interior das instituições de saúde de espaços permanentes de negociação e de produção de ofertas, contribuem de forma decisiva para superação dos modelos de gestão e de trabalho rotinizados, intervenções fragmentadas, verticais em sua estruturação que são pouco efetivas e na maior parte do tempo (CUNHA; CAMPOS, 2010).

A reorganização de saberes e práticas nos espaços de Gestão e Cuidado no âmbito da Atenção Básica, que efetivem tais pressupostos, dependem de um alto grau de articulação entre saberes e práticas dos diferentes profissionais de saúde, neste cenário, que os núcleos de competência profissionais específicos, se enriqueçam a partir da construção de um campo cuidador (CAMPOS, 2003); (BELLINI;PIO;CHIRELLI, 2016); (BISPO; MOREIRA, 2017).

A academia ao aproximar-se dos serviços (de Cuidado e Gestão) orientada pela função apoio, deve estimular a problematização de casos e temas tecendo redes e estabelecendo integração entre sujeitos, potencializando mudanças de percepção e objetivando em suas ações, a ampliação da conexão entre trabalho, academia e prática que valorizem e se oriente, pela singularidade da produção (SALDANHA et al., 2014).

Vale ressaltar, no entanto, que não se muda as perspectivas do SUS nas diferentes esferas políticas investindo apenas em formação de apoiadores, sendo imprescindível, criar 


\section{RevistAleph}

possibilidades além dos limites administrativos e financeiros, rodas de discussões em todos os cenários (universidade, comunidade, usuários) e estabelecer um movimento político e ético para melhorar as produções de saúde na comunidade (CASTRO; CAMPOS, 2014).

Ao considerar a integralidade como um princípio das práticas do cuidado, evidenciase a necessidade de discutir os processos de formação em saúde, discutir as práticas de formação baseadas na dissociação entre atenção e gestão, que ainda tem sua intervenção pautada na queixa (HECKERT; NEVES, 2007).

Roza et al. (2014) destacam que a formação em saúde busca habilitar a capacidade de reflexão sobre o trabalho, consolidando as mudanças nos modos de atenção, sustentado em prática de intervenção sólidas, operacionalizando os conceitos da $\mathrm{PNH}$, na construção de práticas coletivas e valorização dos diferentes atores envolvidos no cuidado em saúde. Isso fortalece a formação dissociada da intervenção, sendo os cenários de atuação, locais privilegiados de aprendizagem.

Essas propostas de mudanças são destacadas nas novas DCN's, em que essa valorização do aprendizado, a partir das práticas e inserção no cotidiano dos serviços gerando mudanças no processo de trabalho e autonomia da aprendizagem, é fundamental no processo de formação do aluno, porém Teles e Arce (2015) mostram que os problemas da fragmentação da formação em saúde ainda são verificados. As mudanças que vêm ocorrendo no currículo da fonoaudiologia permitem a continuidade da fragmentação pela forma desarticulada que esse processo acontece, dificultando a inserção em cenários interdisciplinares.

Integrar ensino-serviço, a partir da vinculação entre gestores, professores e alunos, visa qualificar a formação e auxiliar no desenvolvimento do serviço. É fundamental que a formação esteja pautada em práticas e organização do trabalho com base na problematização dos processos de trabalho e do cuidado.

A fonoaudiologia, mesmo com sua inserção na saúde pública desde os anos 80 , apresenta baixo envolvimento com as políticas públicas de saúde, ressaltando um modelo de clínica reabilitadora, o que mostra a necessidade de formação regulamentada nos aspectos políticos sociais, deslocando o eixo formativo individual e reabilitador. 


\section{RevistAleph}

Assim, a partir do momento que essa integração acontece efetivamente, existe a união entre os envolvidos, diminui-se a distância entre ensino e cuidado, favorece a integração ensino-serviço consolidando o SUS (LEMOS, 2012).

Superar estes distanciamentos requer um planejamento integrado entre os atores dos diferentes níveis de gestão, trabalhadores e representantes das Instituições Formadoras que buscam a integração entre o ensino e os serviços de saúde (TELES; ARCE, 2015).

Entende-se, assim, que a integração ensino-serviço é fundamental para transformação na formação e construção da identidade profissional desse aluno. Estar nos serviços desde o início da graduação possibilita o desenvolvimento de um olhar crítico e reflexivo sobre o cuidado, produzindo mudanças na conduta diante do outro, além de evidenciar a necessidade do uso de tecnologias adequadas como as técnicas de apoio para que esses encontros possibilitem experiências transformadoras para a formação (ROZA et al., 2014).

\section{O estágio em fonoaudiologia institucional e suas práticas de apoio}

O Estágio em Fonoaudiologia Institucional (Componente Saúde Coletiva) tem por objetivo geral formar profissionais Fonoaudiólogos, com sólida base em Saúde Coletiva em suas dimensões técnico-científicas e pedagógicas, capazes de conhecer e intervir sobre os problemas e situações de saúde-doença, com ênfase em sua região de atuação. Apresenta, também, como objetivos a capacidade de atuação futura na promoção da saúde e da qualidade da vida humana, realizando e participando de intervenções organizadas e dirigidas à proteção da saúde, recuperação, reabilitação e educação em saúde, além de desempenhar funções de direção, planejamento, administração, gerência, assessoria, pesquisa e avaliação de práticas de saúde (SAIPPA OLIVEIRA; KOIFMAN; SILVA JR, 2014).

A gestão taylorista, que reforça o trabalho fragmentado é analisado e denunciado pelo Método Paidéia, que se coloca contrário a esse tipo de gestão, trazendo a transversalidade como eixo de mudança da verticalização, partindo do princípio que os envolvidos reformulem seus processos de trabalho, disparando novos modos de gestão e de cuidado (CUNHA; CAMPOS, 2010); (CASSELA; MACHADO, 2017). 


\section{RevistAleph}

Considerando estes pressupostos, o Estágio em Fonoaudiologia Institucional do curso de Fonoaudiologia da UFF desenvolve-se em diferentes locais do município de Nova Friburgo, Região Serrana do Estado do Rio de Janeiro, a partir da identificação das necessidades apresentadas pelos profissionais nos diferentes locais de inserção do estágio. $A$ partir do levantamento dessas demandas, foram definidas propostas de intervenção com olhar na clínica ampliada, no usuário com singularidade e subjetividade, no cuidado em saúde e nos processos de trabalho.

Em todo momento os estagiários são estimulados a agir de forma humanizada e acolhedora, considerando o outro como sujeito, e não apenas como uma queixa ou um diagnóstico preestabelecido. Ao se estabelecer troca entre os diferentes atores envolvidos, iniciam-se os processos dialógicos, construindo as relações e os sujeitos sociais. A partir do momento que a clínica fonoaudiológica desloca seu olhar para essas construções sociais, históricas e culturais, entende-se a pessoa na sua singularidade dentro do processo de cuidado, em que a linguagem é mediadora e fundante dessas interações.

Ao considerar a fonoaudiologia como a área que tem a comunicação e a linguagem como base de suas intervenções, trazer a discussão das estratégias de apoio para formação é fundamental, principalmente por considerar o apoio como uma metodologia capaz de atuar nas relações interpessoais e gerar mudanças no processo de trabalho dos envolvidos na produção do cuidado integral.

A organização dos fluxos de trabalho nos espaços gera transformações na forma de atuar, assim como a presença de alunos nos serviços faz refletir a prática, gerando possibilidade de mudança, como o agir coletivo, autonomia do cuidado, olhar diferenciado diante do outro, escuta qualificada, humanizando as relações entre os diferentes atores desse processo de cuidado e organizando a assistência a partir das mudanças no processo de trabalho.

\section{Percurso metodológico}

Este artigo faz parte de uma dissertação, defendida pela primeira autora, junto ao Programa de Mestrado Profissional em Ensino na Saúde: Formação Interdisciplinar no SUS, pela Escola de Enfermagem Aurora de Afonso Costa, da Universidade Federal Fluminense. Trata-se de uma pesquisa qualitativa e descritiva aprovada pelo Comitê de Ética em Pesquisa, 


\section{RevistAleph}

sob o parecer de aprovação 2.086.912, conforme Resolução do Conselho Nacional de Saúde no 466/2012, do Ministério da Saúde (BRASIL, 2012).

Para garantir a coleta de informações necessárias a construção deste trabalho, foram considerados alguns momentos para se obter o consentimento dos participantes antes da realização do grupo focal, que se caracteriza por uma entrevista em grupo, usado em pesquisas qualitativas, que visa a coleta de informações a partir da interação entre os participantes. Através dele, é possível coletar dados detalhados sobre os temas específicos determinado pelo pesquisador, que estabelece os critérios de formação do grupo, cabendo a ele também estabelecer um ambiente favorável a realização do grupo, propiciando as relações entre os participantes. O grupo focal favorece um debate democrático e acessível nos temas de interesse, é fundamentado em uma relação de horizontalidade entre os participantes (TRAD, 2009).

O processo de coleta de dados desta pesquisa ocorreu a partir da realização de um grupo focal com egressos (formandos 2017.2) do curso de fonoaudiologia de uma Universidade Pública, que se disponibilizaram a responder quatro grandes perguntas abordando os temas acolhimento, formação em saúde, apoio institucional e processo de trabalho, a partir das vivências realizadas no Estágio em Fonoaudiologia Institucional (componente Saúde Coletiva) que acontecem em diferentes cenários da rede de Atenção à Saúde de um Município da Região Serrana.

O grupo focal aconteceu no dia 17 de outubro de 2017 às 17 horas e contou com a presença de 8 alunos, de um total de 14 formandos, todos do gênero feminino, entre 22 e 29 anos de idade, do 9o período (formandos 2017.2) do curso de fonoaudiologia de uma Universidade Federal que haviam finalizado a disciplina "Estágio obrigatório em fonoaudiologia institucional (componente saúde coletiva) " ministrada em dois períodos (7ํㅜ e 8ㅇ).

A coleta de dados foi garantida por meio da elaboração do Termo de Consentimento Livre e Esclarecido (TCLE), de uma carta convite aos participantes do grupo focal, enviados por e-mail para leitura prévia e das questões norteadoras da discussão que buscam entender as conexões entre humanização, apoio e formação.

A interpretação dos achados ocorreu por meio da análise temática a partir da construção de unidades de significação, categorização das narrativas e registro das temáticas 


\section{RevistAleph}

e categorias elaboradas previamente e emergentes, seu resultado foi compreendido enquanto um processo social e de conhecimento multideterminado que ganha contornos específicos de acordo com os processos comunicacionais envolvidos (MINAYO, 2003; 2007).

Os dados produzidos no grupo focal foram gravados e transcritos respeitando de forma fidedigna ao que foi falado, assim como o sigilo da identidade a partir da atribuição de nomes de flores aos participantes da pesquisa.

Os dados desta pesquisa foram levantados através de uma discussão a partir de quatro grandes temas disparadores, sendo eles acolhimento, apoio institucional, formação e processo de trabalho, a respeito do impacto das vivências em diferentes cenários da rede a partir do estágio em fonoaudiologia institucional em sua formação e construção da identidade profissional. Após a análise e transcrição dos dados foram identificadas categorias analíticas, sendo elas, humanização da atenção, apoio institucional e formação em saúde.

Seus achados foram organizados em três categorias analíticas, sendo eles humanização da atenção, formação em saúde e apoio institucional, com suas respectivas categorias empíricas para discussão, dentre eles estão o acolhimento, subjetividade, humanização do atendimento, integralidade do cuidado, atuação em equipe multidisciplinar e percepção da prática.

Para fins de elaboração deste artigo considerou-se os dados referentes as ações de apoio institucional e suas categorias empíricas (relação teoria x prática, construção da identidade profissional e aprendizagem a partir da prática).

\section{Resultados e discussões}

Integrar ensino-serviço, a partir da vinculação entre gestores, professores e alunos, visa qualificar a formação e auxiliar no desenvolvimento do serviço (LEMOS, 2012).

Nesse sentido, Liz analisa seu processo de aprendizagem "eu nunca fui a aluna nota dez, sempre era a mediana, não reprovava, mas também não tirava notão, e ficava ali na média. E aí, vem esse medo de: nossa será que eu vou ser boa?" e percebe que o estágio "foi o momento que eu me encontrei, que eu vi, que eu não precisava tirar as notas pra ser uma boa(...) né, pratica, e eu tive muito mais interesse de estudar agora do que antes quando era uma prova". 


\section{RevistAleph}

Assim como Liz, Margarida relata a importância do estágio em seu processo de construção profissional: "quando a gente entra no estágio, a gente vê o que que leva uma pessoa a fumar, não é porque ela quer fumar, é uma dependência, é uma doença mesmo. |...। então acho que estar nesse estágio me faz ter essa sensibilidade. Eu não vou mais desse estágio em diante até a minha prática profissional, simplesmente chegar pro paciente e falar 'não, você tem que parar de fumar e ponto', (...) entender qual é o contexto familiar, qual é o contexto social, por que ele tá fumando, então faz a gente ter esse olhar mesmo diferencial nesse caso".

Violeta também apresenta uma análise positiva das experiências do estágio, diz que "Eu acho que se eu não tivesse pegado esse estágio no CAPS, é uma visão diferente da clínica, eu acho que faltaria, como a Margarida falou, na minha maleta um pedação de alguma área que eu gostaria de ter conhecido na minha formação |... | experiência boa que eu teria deixado pra traz na graduação".

As discussões da integração ensino-serviço evidenciam a grande dificuldade de efetivação deste conceito. Mostram o grande afastamento entre o serviço e as instituições de ensino, com pouco diálogo e limitação de ações, gestão, organização e participação do usuário. Essa dificuldade surge pelo prévio planejamento de ações pelas instituições desconsiderando o serviço e queixas das instituições do modelo tecnicista e de produtividade adotado pelos serviços (TELES; ARCE, 2015).

Acácia mostra essa defasagem, pois, "Eu acho que na nossa graduação, a saúde coletiva precisava de um espaço maior, uma valorização maior, que a gente vê muito nos primeiros períodos, e a gente não vê a importância da saúde coletiva. |...। mas a gente vê que a realidade ali a gente precisa da saúde coletiva, e chega no institucional, gente, cadê a nossa bagagem de saúde coletiva?” A fala de Acácia mostra que a saúde coletiva não é valorizada durante a graduação, se restringindo apenas às disciplinas da área, não perpassando as demais áreas da fonoaudiologia. A visão de que é necessário conexão entre todas as áreas não é potencializada, e gera insegurança ao iniciar o estágio, como mostra Hortência: "É o primeiro contato que a gente tem com esse estágio, já começa por aí, da dificuldade inicial. É o único estágio que a gente não tem preparação teórica pra vir. A gente é preparada a graduação inteira pra atender clinicamente, e quando a gente vai pro estágio institucional é 


\section{RevistAleph}

uma coisa muito mais ampla, a gente tem que pegar conhecimento de várias disciplinas que a gente fez diferentes, diferentes áreas, juntar tudo ... E da saúde coletiva".

Violeta complementa que a "formação da gente não faz com que a gente não trabalhe em grupo, mas sentar na mesa atender o seu paciente, mas ali com aquela disciplina eu pude perceber que eu cheguei mais tranquila no estágio", e evidencia a importância dessa relação para construção de seu processo de trabalho, impactando nos demais estágio e futuramente em sua atuação profissional.

Tem-se no método Paidéia uma possibilidade de reformular os mecanismos tradicionais de gestão (BARROS et al., 2014), sendo usado em diferentes níveis de ensino, em que são combinadas discussões de casos, reflexões sobre a prática e materiais teóricos. A metodologia aposta na capacidade de análise e cogestão dos profissionais envolvidos (OLIVEIRA; CAMPOS, 2017). Margarida relata que a experiência com o apoio "fez a gente refletir nossa prática", e Rosa complementa essa reflexão ao dizer que "consegui me achar lá (no estágio institucional). Que eu podia agir mais, que não precisava ser aquela coisa tão quadrada. Tenho que ser uma fonoaudióloga quadrada, tenho que fazer isso assim. Não, eu vou fazer do meu jeito, utilizando de outros recursos pessoais meus, dentro do profissional(...), eu consigo hoje ver e analisar estratégias que consiga atingir a queixa do paciente, que hoje eu aprendi que é o paciente, a vontade do paciente, não a minha. "

As vivências, valorizadas no apoio, estão ligadas ao "aprender fazendo" que se destaca como principal ferramenta para formação de apoiadores. Acredita-se que o trabalho interdisciplinar deveria fazer parte da formação em saúde, promovendo articulação da prática e gestão para promover mudanças, ressignificando a prática, propondo aprendizagem por meio de vivências, tendo a formação pedagógica aliada às políticas públicas e subjetividade dos sujeitos (OLIVEIRA; CAMPOS, 2017).

Essa visão é confirmada por Violeta quando diz que "a prática, na minha opinião, ela ainda sobressai (...) a teoria te dá a base, mas a prática molda essa teoria de acordo com o que você vai ver no dia a dia", da mesma forma que Margarida exemplifica essa aprendizagem na prática ao comparar seu aprendizado teórico e sua vivência ao relatar que "na disciplina teórica são tantas coisas que a gente se preocupa...são aquelas disciplinas básicas né... vem as disciplinas específicas, vêm as patologias, e a gente fica dentro daquela caixinha. Quando a gente chega no estágio, a gente ainda tá muito dentro da caixinha, então ah, quando o 


\section{RevistAleph}

supervisor fala "ah hoje vocês vão tocar o grupo". Tipo, dá um mini infarto (risos) e como que eu vou fazer isso? aí tá, a gente vai, se prepara, toda aquela dinâmica, a gente se programa tudo, fala assim "vai bombar!". Aí o grupo tem uma hora, em cinco minutos a dinâmica já se esgotou, o que que você vai fazer? Você está sozinho na sala, só você e o grupo... E a gente só aprende isso não prática".

Rosa complementa relatando que "... nunca fui lá muito boa na teoria... quando eu estudava a teoria eu não conseguia ver aquilo, eu falava assim... eu lia, lia e tá, não tá fazendo sentido nenhum pra mim, aí eu passava, quando eu comecei a ver a prática, eu já fiz ao contrário, eu já comecei a conseguir encaixar aquilo que falavam pra mim dentro do paciente"

Já Acácia traz uma reflexão sobre o processo de formação e mostra importância da relação da saúde coletiva durante toda graduação, dizendo "que poderia ter sido trabalhado mais, assim nas disciplinas e tal, pra isso ficar mais ... pra isso ficar mais enfatizado ainda, porque nem todo mundo às vezes pegou essas questões, né. |... l então assim o institucional é um estágio pra gente abrir a mente assim, do que que a gente pode fazer, dessa construção do nosso papel em lugares que a gente nem imaginava."

Iris complementa percepção, pois, entende que "isso não é falado, é como se falassem assim: vocês têm que saber tudo! Vocês têm que chegar lá e tem que saber! Você tem que estar com o paciente, fazer uma anamnese, você já tem que saber identificar o que que ele tem, pra fazer, aplicar um protocolo... e não é bem assim, não é!".

São esses momentos e reflexões que fortalecem a construção do conhecimento, e reforçam a necessidade de integrar ensino-serviço, potencializando as rotinas dos serviços, apresentando uma formação baseada nas políticas públicas, formando no SUS e para o SUS.

\section{Conclusão}

A vivência em diferentes cenários pelos alunos neste estágio proporcionou a construção crítica de sua formação e identidade profissional por meio da imersão em práticas cuidadoras em saúde com foco no sujeito integral, porém evidenciou situações que precisam ser repensadas ainda na graduação, na busca por melhores relações interpessoais, possibilitando mudanças no processo de trabalho e da gestão necessários para uma reformulação do modelo assistencial, a partir da humanização das relações, com atenção 


\section{RevistAleph}

digna e responsável com estabelecimento de vínculo e acolhimento ao usuário. A Formação em saúde reforça o atendimento fragmentado existente no SUS, não apresentando esse olhar diferenciado para a atenção e o cuidado em saúde.

A dificuldade em compreender alguns conceitos é evidenciada na hora de colocar em prática a teoria aprendida, gerando uma insegurança ao pensar a identidade profissional que está se construindo. O apoio institucional surge como um dispositivo para superar a fragmentação do serviço. A resistência às mudanças não se apresenta apenas no serviço em saúde, mas também na formação, em que a problematização do trabalho e do cuidado não estão em evidência.

As diferentes narrativas dos participantes do grupo focal reforçam o quanto a inserção do aluno no ambiente do SUS ainda em seu período de formação pode ser importante para construção de sua identidade profissional ao apresentar diferentes possibilidades de atuação fonoaudiológica, por ser uma área que está presente nos diferentes níveis de atenção à saúde e podendo fazer parte de diversos pontos da rede de cuidados, incluindo a presença no acolhimento, trazendo para sua construção o olhar ampliado e a escuta qualificada, contribuindo para organização da porta de entrada e responsabilização pelo cuidado.

É perceptível a partir das falas dos participantes, que a graduação forma para a clínica, não para atuar no SUS, e que não existe relação entre as disciplinas das demais áreas da fonoaudiologia com a saúde coletiva, potencializando uma visão fragmentada do cuidado, sem foco no sujeito, mas nas hipóteses diagnósticas. A valorização da saúde coletiva na graduação surge na prática, quando percebem que seus conceitos são fundamentais para atuação profissional.

A fonoaudiologia precisa estar envolvida no processo de mudança dos serviços de saúde, e apresentar desde a graduação envolvimento com as políticas públicas de saúde, valorizando uma formação generalista, reflexiva e humanizada, através de práticas de construção do cuidado, com acolhimento, escuta ampliada, vínculo e resolutividade.

\section{Referências}

ANDRADE, M.A.C. et al. Institutional support: democratic strategy in the everyday practices of the Brazilian Health System (SUS). Interface (Botucatu), 18 Supl 1:833-44. 2014. 


\section{RevistAleph}

AYRES, J.R.C.M. Hermenêutica e humanização das práticas de saúde. Ciência \& Saúde Coletiva, Rio de Janeiro, v. 10, n. 3, p. 549-560, jul./set. 2005.

AYRES, J.R.C.M. Uma Concepção Hermenêutica de Saúde. Physis. Rev. Saúde Coletiva, Rio de Janeiro, 17(1):43-62, 2007.

BARROS, M.E.B. et al. $\mathbf{O}$ apoio institucional como dispositivo para a implantação do acolhimento nos serviços de saúde. Comunicação Saúde Educação, 18 Supl. 1:1107-17; 2014.

BELLINI, M.; PIO, D.A.M.; CHIRELLI, M.Q. O apoiador institucional da Atenção Básica: a experiência em um município do interior Paulista. Saúde Debate, v. 40, n. 108; 23-33. Rio de Janeiro, 2016.

BENEVIDES, R.; PASSOS, E. A humanização como dimensão pública das políticas de saúde. Ciência \& Saúde Coletiva, v. 10, n. 3, p. 561-571, jul./set. 2005.

BISPO JUNIOR, J.P.; MOREIRA D.C. Educação permanente e apoio matricial: formação, vivências e práticas dos profissionais dos Núcleos de Apoio à Saúde da Família e das equipes apoiadas. Cad. Saúde Pública; 33-39. 2017.

BRASIL. Ministério da Saúde. Secretaria de Atenção à Saúde Núcleo Técnico da Política Nacional de Humanização: Acolhimento nas práticas de produção de saúde. 2a edição -2.a reimpressão -Série B. Textos Básicos de Saúde -Brasília - DF, 2008.

BRASIL. Conselho Nacional de Saúde. Resolução n 466, de 12 de dezembro de 2012. Brasília, 2012. [cited 2016 Out 10] Available from:

http://bvsms.saude.gov.br/bvs/saudelegis/cns/2013/res0466_12_12_2012.html

CAMPOS, G.W.S. Um método para análise e co-gestão de coletivos. São Paulo: Hucitec, 2000.

CAMPOS, G.W.S. A Clínica do sujeito: por uma clínica reformulada e ampliada. In: CAMPOS, G.W.S. (org.) Saúde Paideia. São Paulo. Hucitec, 2003.

CASSELLA, N.A.; MACHADO, F.R.S. Apoio Institucional: a percepção dos apoiadores em uma maternidade pública de Alagoas. Trab. Educ. Saúde, Rio de Janeiro, 2017.

CASTRO, C.P.; CAMPOS, G.W.S. Apoio Institucional Paidéia como estratégia para Educação Permanente em saúde. Trab. Educ. Saúde, Rio de Janeiro, v. 12 n. 1, p. 29-50, jan./abr. 2014.

COSTA, J.C. et al. Acesso ao serviço de fonoaudiologia: A implantação do acolhimento no município de Toledo-PR. Rev. CEFAC. Set-Out; 14(5): 977-983 2012.

CUNHA, G.T.; CAMPOS, G.W.S. Método Paidéia para Co-gestão de coletivos organizados para o trabalho. ORG \& DEMO, Marília, v.11, n.1, p. 31-46, jan./jun., 2010.

DESLANDES, S.F.; MITRE, R.M.A. Communicative process and humanization in healthcare. Interface Comunic., Saúde, Educ., v.13, supl.1, p.641-9, 2009. Disponível em: http://www.conselho.saude.gov.br/web_comissoes/conep. Acesso em 10 de outubro de 2016.

FIGUEIREDO, M.D.; CAMPOS, G.W.S. Paideia support as a methodology for healthcare education processes. Interface (Botucatu). 2014; 18 Supl. 1:931-43. 
FURLAN, P.G; CAMPOS, G.W.S. Support research: participatory research and the Paideia method of institutional support. Interface (Botucatu). 2014; 18 Supl 1:885-94.

HECKERT, A.L.C.; NEVES, C.E.A.B. Modos de formar e modos de intervir: quando a formação se faz potência de produção do coletivo. In: MATTOS, R. A.; BARROS, M.E.B.; PINHEIRO, R. (Org.). Trabalho em equipe sob o eixo da integralidade: valores, saberes e práticas. 1 ed. Rio de Janeiro: CEPESCIMS/UERJABRASCO, 2007, v. 1, p. 145-160.

LEMOS, M. A integração ensino-serviço no contexto da formação do fonoaudiólogo: um relato de experiência da prática de ensino-aprendizagem no estágio de saúde coletiva - Revista Baiana de Saúde Pública v.36, n.4, p.1068-1076 out./dez. 2012.

MINAYO, M.C.S. Hermenêutica-Dialética como caminho do pensamento social. In: MINAYO, M.C.S.; DESLANDES, S.F. (Org.). Caminhos do pensamento: epistemologia e método. Rio de Janeiro: Fiocruz; 2003. p. 83-107.

MINAYO, M.C.S. O Desafio do Conhecimento: Pesquisa Qualitativa em Saúde. 10. Ed. São Paulo: HUCITEC, 2007.

OLIVEIRA, M.M.; CAMPOS G.W.S. Apoios matricial e institucional: analisando suas construções. Ciênc Saúde Coletiva 2015; 20: 229-38.

MINAYO, M.C.S. Formação para o Apoio Matricial: percepção dos profissionais sobre processos de formação. Physis. Revista de Saúde Coletiva, Rio de Janeiro, 27 [2]: 187-206, 2017. Available from: https://www.scielosp.org/pdf/physis/2017.v27n2/187-206/pt

PAIXÃO, L.; TAVARES, M.F.L. The development of the project "Networking Support" as an institutional strategy. Interface (Botucatu). 2014; 18 Supl 1:845-58.

PASCHE, D.F. Gestão e subjetividade em saúde. In: Saúde Coletiva diálogos contemporâneos. PASHE, D.F.; CRUZ, I.B.M (Org.). ljuí, Ed. Unijuí, 2006.

PASCHE, D.F. Humanizar a formação para humanizar o SUS- In: BRASIL. Ministério da Saúde. Secretaria de Atenção à Saúde. Política Nacional de Humanização. Formação e intervenção / Ministério da Saúde, Secretaria de Atenção à Saúde, Política Nacional de Humanização. Brasília: Ministério da Saúde, 2010. 242 p. (Série Textos Básicos de Saúde) (Caderno HumanizaSUS; v.1).

PINHEIRO, R. et al. Experienciação, Integralidade e Direito à Saúde: articulando conceitos, práticas de pesquisa e percepções para (re)pensar o agir do apoiador institucional - In: PINHEIRO, R.; LOPES, T.C.; SILVA, F.H.\& JUNIOR, A.G.S. Práticas de apoio e integralidade no sus: por uma estratégia multicêntrica de pesquisa. Rio de Janeiro: CEPESC\ABRASCO, 2014. Pág.27-43.

RIBEIRO, M.G. Proposta de Acolhimento Diferenciado a Pais de Crianças com Queixas de Alterações de Linguagem. Rev. soc. bras. fonoaudiol., São Paulo, v. 17, n. 3, p. 374, 2012.

RODRIGUES, A.P.M. A inserção do fonoaudiólogo na atenção básica de saúde do município de Nova Friburgo-RJ. Trabalho de Conclusão de Curso apresentado a Universidade Federal Fluminense como requisito parcial para obtenção do grau Bacharel em Fonoaudiologia. 53.p;2014.

ROZA, M.M.R. et al. A experiência de um processo de formação articulando humanização e apoio institucional no trabalho em saúde. Interface (Botucatu). 2014; 18 Supl 1:1041-52. 
SAIPPA OLIVEIRA, G.; KOIFMAN, L.; PINHEIRO, R. Seleção de conteúdo, ensino-aprendizagem e currículo na formação em saúde. In: PINHEIRO, R., CECCIM, R.B., MATTOS, R.A. (Org.). Ensinar saúde: a integralidade e o SUS nos cursos de graduação na área da saúde. Rio de Janeiro: IMS/UERJ/ABRASCO; p. 205-28.2006.

SAIPPA OLIVEIRA, G.; KOIFMAN, L.; SILVA JR, A.G. Apoio, gestão e democracia institucional: o potencial formativo. In: PINHEIRO, R.; SILVA, F. H.; LOPES, T. C.; JUNIOR, A.G.S. Práticas de Apoio e a Integralidade no SUS: por uma estratégia de rede multicêntrica de pesquisa. Rio de Janeiro: Cepesc / Ims / Uerj /Abrasco; 368 p. 2014.

SALDANHA, O.M.F.L. et al. Clinic-school: innovative institutional support to the practices of management and health care as part of the teaching-work integration. Interface (Botucatu);18 Supl 1:1053-62. 2014.

SANTOS FILHO, S.B.; BARROS, M.E.B.; GOMES, R.S. The National Humanization Policy as a policy produced within the healthcare labor process. Interface - Comunic. Saude, Educ., v.13, supl.1, p.60313, 2009.

SILVA, F.H.; BARROS, M.E.B.; MARTINS, C.P. Experimentations and reflections on institutional support within healthcare: study starting from HumanizaSUS. Interface (Botucatu); 19(55): 1157-68. 2015.

TELES, M.W.P.; ARCE, V.A.R. Formação e Pet-Saúde: experiências de estudantes de fonoaudiologia na Bahia - Rev. CEFAC. maio-jun.; 17(3): 695-706. 2015.

TRAD, L. Grupos focais: conceitos, procedimentos e reflexões baseadas em experiências com o uso da técnica em pesquisas de saúde. Physis. Revista de Saúde Coletiva, Rio de Janeiro, 19 [3]: 777$796,2009$. 


\title{
AS VOZES DAS CRIANÇAS E EXPERIÊNCIAS INSTITUINTES NA EDUCAÇÃO ANTIRRACISTA
}

\section{CHILDREN'S VOICES AND INSTITUTING EXPERIENCES IN ANTI-RACIST EDUCATION}

\author{
Daise dos Santos Pereira ${ }^{64}$ \\ Kirce Correa Bermute ${ }^{65}$
}

\section{Resumo}

O artigo apresenta experiências escolares, a partir da lei federal 10.639/03, percebida por nós como marcos de experiências instituintes. O público-alvo foi de crianças do Ensino Fundamental I de uma escola no município de Magé-RJ. A construção do texto buscou alicerçar-se na contribuição analítica de Frantz Fanon que compreendeu a libertação das mentes pela luta de ideias e prática. Os Projetos de trabalho foram caminhos metodológicos, envolvendo registros em caderno de campo e autobiográficos pelas crianças. A Sociologia da Infância, contribui para o corpo teórico-metodológico com as categorias: Reprodução Interpretativa e Etnografia Longitudinal. E reconhecendo que as crianças são ativas e inventivas, Michel de Certeau é chamado para a conversa, revelando suas 'Artes de Fazer'.

Palavras-chave: Vozes das crianças. Experiências instituintes. Artes de fazer. Educação antirracista. Sociologia da infância.

\begin{abstract}
The article presents school experiences, from the federal law 10.639/03, perceived by us as milestones of instituting experiences. The target audience was for elementary school children from a school in the municipality of Magé-RJ. The construction of the text sought to be based on the analytical contribution of Frantz Fanon, who understood the liberation of minds through the struggle of ideas and practice. The work projects were methodological paths, involving field notebook and autobiographical records by the children. The Sociology of Childhood, contributes to the theoretical-methodological body with the categories: Interpretative Reproduction and Longitudinal Ethnography. And recognizing that children are active and inventive, Michel de Certeau is called into the conversation, revealing his 'Arts of Making'.
\end{abstract}

Keywords: Children's voices. Instituting experiences. Arts of making. Anti-racist education. Childhood sociology.

\footnotetext{
64 Mestra em Diversidade e Inclusão (CMPDI) pela Universidade Federal Fluminense - Niterói/Brasil (2016). Especializada em Ensino de História e Ciências Sociais (UFF), Graduada em Pedagogia (UFF). Professora do Ensino Fundamental I na Prefeitura Municipal de Magé e Petrópolis. E-mail: daise2009@gmail.com / https://orcid.org/0000-0001-7743-4171

65 Graduação em Filosofia pela Universidade Federal do Rio de Janeiro (2018). Professora concursada do Ensino Fundamental I na Prefeitura Municipal de Magé. E-mail: kircebermute@gmail.com / https://orcid.org/00000002-9101-615X
} 
'Tia, se a gente pintar de preto, a cor que eu sou, todo mundo vai achar feio.'

(Narrativa infantil ${ }^{66}$ - autor: Bruno C.)

Há algum tempo, descobrimos o intelectual, militante político e anticolonialista francês Frantz Omar Fanon (1983). Acreditamos que ao falar sobre representatividade negra e construção de novas subjetividades no campo educacional, torna-se imprescindível diálogos com autores que buscaram interpretar as relações étnico-raciais de maneira crítica e reflexiva.

Assim, iniciamos esse texto chamando para a conversa um filósofo, que em seu tempo, lutou pela libertação das mentes, deixou um legado político na luta pela descolonização de países do terceiro mundo, além de obras ${ }^{67}$ que potencializam as reflexões contemporâneas sobre caminhos possíveis para a superação do racismo.

Também abrimos essa reflexão com uma epígrafe, que revela uma narrativa infantil do cotidiano escolar. A escolha por evidenciar a voz infantil, ocorre por entendermos que a criança é um ator social no processo educativo e grande aliada na compreensão das relações mais complexas da sociedade. Tais argumentos, se estruturam na Sociologia da Infância (CORSARO, 2005; SARMENTO, 2005, 2011), enquanto constructo epistemológico, que legitima a criança como produtora de cultura e reveladora das possibilidades da estrutura social (SARMENTO, 2005, p. 363). Nesse sentido, defendemos que: uma prática docente comprometida com a diversidade, com a escuta e a problematização das narrativas infantis expressadas no dia a dia, estará mais sensível a perceber os indícios que torna obrigatório o ensino das questões étnico-raciais desde a mais tenra idade (PEREIRA, 2018). A seguir, um registro que contextualiza a voz que abre esse texto, a partir de uma narrativa docente:

No primeiro dia de aula do ano letivo de 2019, distribuí para o 4을 ano um desenho para colorir que representava algumas crianças chegando na escola também em seu primeiro dia de aula. Após uns dez minutos, percebi que um grupo de crianças discutiam para ver quem pegava o "lápis cor de pele" primeiro. Este, tratava-se de um lápis rosa, bem claro. Então, eu fui até a

\footnotetext{
${ }^{66}$ Para Kramer (2002, p. 53), autoria se relaciona à autorização, à autoridade e à autonomia. Nesse sentido, as narrativas e imagens infantis presentes no texto, estão autorizadas pelas crianças e seus responsáveis.

67 Segundo Costa (2016), Frantz Fanon (1925-1961) escreveu apenas três livros: Peau noir, masques blancs (1952), L'an cinq de la Révolution Algérienne (1959) e Les damnés de la terre (1961). Mas a obra Pele Negra, Máscaras Brancas (1952) é a que dialoga intimamente com este trabalho. Você entenderá o porquê.
} 
frente da sala e bastante incomodada com a discussão, perguntei: 'Por que essa cor é cor de pele? É cor da pele de quem?’ Várias foram as respostas, mas a resposta que mais me causou desconforto, foi a de um aluno que respondeu: 'Tia, se a gente pintar de preto, a cor que eu sou, todo mundo vai achar feio.' Mesmo depois de uma longa explicação sobre o belo, e o que deve ser considerado belo, fiquei incomodada e percebi que a problemática em questão deveria ser muito mais explorada, mais discutida, pois, a resposta do pequeno, era somente uma camada superficial de uma questão muito mais complexa: a falta de representatividade negra dentro da escola e da comunidade (Registro do caderno de campo. BERMUTE, $2019^{68}$ ).

A cena evidencia narrativas comuns e emblemáticas do cotidiano de muitos professores e escolas. Não obstante, embora sejam recorrentes, a sua problematização, em prol de processos educativos que positivem as relações étnico-raciais, ainda faz parte de silêncios e invisibilidades.

Narrativas, cotidiano, invisibilidades e silêncios, nos remetem, inicialmente a dois autores que nos são caros e acreditamos que podem potencializar as redes reflexivas para a construção de uma educação antirracista.

Frantz Fanon, com a sua prece "Oh, meu corpo, faça sempre de mim um homem que questiona!", evidencia a importância da fala, bem como da problematização do lugar do sujeito colonizado. Nesse sentido, defendeu que a libertação das mentes só poderia ocorrer a partir da desconstrução de práticas discursivas, impactando a construção de outras/novas subjetividades (PEREIRA, 2020). Para sair da invisibilidade e do sentimento do não-ser, o silêncio não cabia. E o caminho para tal, era, senão, por meio de uma luta de ideias, luta prática e de reinvenção.

O segundo autor, nos remete ao cotidiano e às narrativas comuns dos sujeitos. Michel de Certeau ${ }^{69}$, historiador francês, conhecido por seus estudos sobre práticas culturais para a compreensão das práticas cotidianas, dizia que: o cotidiano é aquilo que nos é dado a cada dia (ou que nos cabe em partilha), nos pressiona dia após dia, nos oprime [...] O cotidiano é aquilo que nos prende intimamente, a partir do interior (CERTEAU, 1996, p. 36). E continua, afirmando que, o que interessa ao historiador do cotidiano é o invisível.

\footnotetext{
${ }^{68}$ A professora Kirce Bermute é uma das autoras deste artigo.

${ }^{69}$ Certeau nasceu na França em 1925. Foi um autor que buscou na interdisciplinaridade um modo de ser e fazer. Por isso, seus caminhos de formação são múltiplos, como: filosofia, letras clássicas, história e teologia. Foi um jesuíta (Companhia de Jesus-1950) e conciliou a vida religiosa com a vida de pesquisador. Lecionou em Paris na Ecole des Hautes Etudes em Sciences Sociales e na Universidade da Califórnia.
} 


\section{RevistAleph}

Assim, parafraseando Certeau, asseguramos que enquanto professoras que refletem sobre/com o cotidiano e militantes de educação antirracista, o que nos interessa são as narrativas infantis que revelam subjetividades negadas e silenciadas que reforçam a desvalorização de peles negras e indígenas. O que nos interessa é reconhecer a criança como sujeito de direitos e de voz legítima. Por isso, tirá-la da invisibilidade é urgente, para que seja a nossa aliada na luta por uma sociedade antirracista.

E como entendemos que a matéria-prima do processo educativo é de caráter relacional, essa luta só ganha potência quando pensada a partir das relações de alteridade, onde o Outro é Legítimo Outro (MATURANA, 2007).

Neste texto, o nosso Outro se revelou com um grito invisível: 'Tia, se a gente pintar de preto, a cor que eu sou, todo mundo vai achar feio.' Um grito que prendeu sua interlocutora intimamente e a provocou a reafirmar seu compromisso com a educação como prática da liberdade (FREIRE, 1999).

Além disso, foi também um grito que ecoou, para além daquele espaço e tempo ${ }^{70}$, levando muitos a refletirem sobre invisibilidade, representatividade negra e histórias que importam.

E hoje, estamos aqui para contar as experiências instituintes a partir de uma perspectiva histórica baseada na lei federal 10.639/03. Experiências essas, com muitas "artes de fazer" ${ }^{\prime 11}$ dos praticantes do cotidiano (CERTEAU, 1996), cujas narrativas invisíveis muito nos interessam.

Importante ressaltar que a categoria Instituinte, que adjetiva a palavra experiência e que é uma das marcas da RevistAleph, pode ser entendida como o movimento dos sujeitos que pensam e fazem a educação para além das amarras burocráticas e engessadoras que reduzem as ricas experiências que são desenvolvidas, fazendo e refazendo a escola (MOREIRA et.al., 2018, p. 2).

\footnotetext{
${ }^{70} \mathrm{~A}$ emblemática narrativa infantil motivou a professora Kirce Bermute a construir o projeto pedagógico 'Construindo Identidades sob uma perspectiva histórica baseada na lei 10.639'. O projeto foi premiado no 10 Prêmio Paulo Freire da Assembleia Legislativa do Estado do Rio de Janeiro - Alerj na modalidade Experiência Pedagógica no Ensino Fundamental.

${ }^{71}$ Expressão que intitula a consagrada obra de Michel de Certeau, $A$ invenção do cotidiano l: as artes do fazer (1994).
} 


\title{
RevistAleph
}

Cabe dizer que, o lugar das astúcias, das "artes de fazer" e das táticas, é também de onde o professor fala. As narrativas aqui compartilhadas não são meros acasos, porque afinal de contas, ouvir o professor e ouvir o estudante é o que falta às políticas educacionais.

E nesse movimento de compartilhar experiências instituintes no campo do ensino da história da África e Cultura Afro-brasileira e Africana, enfatizamos ao longo do texto, algumas categorias conceituais do historiador Michel de Certeau que contribuem para pensarmos na invenção do cotidiano escolar, pelas mãos dos atores sociais.

As expressões são basicamente: táticas de praticantes, táticas de resistência, ações do tipo tático, inventividade, brechas, e as artes de fazer. Todas elas nos apontam para a direção da desconstrução de práticas discursivas, a partir da não conformidade com o instituído. Mas uma desconstrução baseada na inventividade e criatividade.

Esperamos que os caminhos percorridos pelos praticantes do cotidiano do Ensino Fundamental (4으으 ano) da escola municipal Tiradentes, localizada em Magé/Baixada Fluminense do RJ, inspirem ações do tipo tático a muitos docentes Brasil afora, e quiçá extrapole fronteiras.

\section{De um grande quilombo, nasce um pensar-fazer instituinte}

\author{
É uma história verdadeira \\ Não duvide, tenha fé \\ Contando a trajetória \\ De uma importante mulher \\ Chamada Maria Conga \\ Heroína de Magé \\ (Gilmar Souza - Poeta Cordelista)
}

Magé $^{72}$ é um município da Baixada Fluminense, situado na Região Metropolitana do Rio de Janeiro, localizado ao fundo da Baía de Guanabara. Sua criação nos remete a memórias - em sua maioria, únicas - que os livros didáticos de história narram. É comum vermos a história de Magé sendo iniciada com a figura do português Simão da Mota (Nome da principal

\footnotetext{
72 Segundo dados do IBGE (2019), a população está estimada em 245.071 pessoas.
} 


\section{RevistAleph}

avenida da cidade, inclusive), que no século $\mathrm{XVI}^{73}$ recebeu a doação de uma sesmaria localizada no morro da Piedade, região com forte presença de populações tradicionais (comunidades quilombolas e caiçaras).

As terras mageenses, originariamente habitadas por indígenas, têm fortes marcas dos povos minoritários, ou seja: povos indígenas e quilombolas, sobretudo. A respeito da categoria minoria, é importante ressaltar que:

[...] a categoria minoria pode causar confusão quando referida a grupos de mulheres, negros, indígenas, crianças, população pobre, já que estes representam a maioria. Importante esclarecer que, no discurso hegemônico, minoria dá a ideia de grupo inferior. No entanto, esse conceito na Contemporaneidade vem romper com as questões quantitativas, dando vez às demandas das singularidades dos grupos culturais (PEREIRA, 2016, p.9).

Assim, falar de educação para as relações étnico-raciais nas salas de aulas mageenses, partindo de narrativas locais e das vozes dos sujeitos ordinários do cotidiano (CERTEAU, 1996), representa uma luta pelo fortalecimento das subjetividades dos estudantes, herdeiros de histórias de resistência.

Em Magé, lugar de heróis, tradições e três territórios quilombolas ${ }^{74}$, essa luta se faz urgente. Sim, vivemos e trabalhamos em um grande quilombo e nossa responsabilidade, enquanto profissionais da educação, é assegurar que nossos estudantes se apropriem de suas histórias de maneira afetiva e real. Segundo as Diretrizes Curriculares Nacionais para a Educação das Relações Étnico-Raciais e para o Ensino de História e Cultura Afro-Brasileira e Africana (BRASIL, 2004), a instituição de ensino, bem como as instâncias superiores devem garantir que:

A escola enquanto instituição social responsável por assegurar o direito da educação a todo e qualquer cidadão, deverá se posicionar politicamente, como já vimos, contra toda e qualquer forma de discriminação. A luta pela superação do racismo e da discriminação racial, é pois, tarefa de todo educador, independentemente de seu pertencimento étnico-racial, crença religiosa ou posição política (p. 16).

\footnotetext{
${ }^{73}$ Segundo Sampaio (1994), a povoação de Nossa Senhora da Piedade foi transformada em freguesia em 1696, e elevada à categoria de Vila em 1789.

74 O Quilombo de Maria Conga foi o primeiro território a ser certificado e reconhecido pela Fundação Palmares no ano de 2017. Os Territórios Quilombolas do Feital (Bairro de Piedade/ 1을 Distro) e Kilombá (Bongaba/6으 Distrito) tiveram suas certificações no ano de 2018.
} 


\section{RevistAleph}

No âmbito das políticas públicas, no município de Magé, muito recentemente, alguns passos foram dados com a construção de um dispositivo legal ${ }^{75}$ que inclui a História e Cultura Afro-brasileiras e Indígenas nos currículos da Rede Municipal de Ensino. Não obstante, para a superação de culturas e práticas escolares marcadas por lógicas coloniais, reducionistas e segregadoras da diversidade, ainda há ainda muito o que se conquistar.

E concordamos que as experiências instituintes a partir de uma perspectiva histórica baseada na lei federal 10.639/03, favorecem a construção de uma educação de respeito e diálogo com a cultura africana e afro-brasileira. Afinal, o que deve nos orientar é a garantia dos direitos humanos, que como outrora afirmou Boaventura de Sousa Santos (2013), deve partir de uma concepção multicultural, dialógica e solidária.

\section{Caminhos metodológicos: entre histórias e invenções}

A infância faz parte da sociedade CORSARO ( 1997, p.5)

A Sociologia da Infância (CORSARO, 2005), perspectiva que postula a criança como sujeito histórico, de direitos e com voz competente, se recusa a pensar em uma concepção homogeneizante e passiva da criança. Mas nem sempre foi assim, ou seja, a criança ao longo da história, nem sempre foi reconhecida como ator nas relações sociais. Basta lembrar da expressão iluminista "o homem nasce como se fosse uma tábula rasa", do filósofo John Locke (séc. XVII). Em outras palavras, a criança é um papel em branco, onde o adulto escreve sua cultura.

Até o final do século XX, a imagem da criança passou por várias reestruturações, sendo ela: um miniadulto, sem fala, enfrentou altas taxas de mortalidade, foi reconhecida com alma pela igreja, foi infantilizada e também subestimada em suas invenções. As imagens narradas fazem parte do trabalho do historiador francês, Philippe Ariès.

\footnotetext{
75 Importante destacar a criação de um núcleo de formação para o ensino das relações étnico-raciais no Município. A COPIED (Coordenação de Promoção à Igualdade Étnico-raciais e Diversidade), no qual uma das autoras deste artigo integra, faz parte de um conjunto de políticas públicas municipais que vêm sendo implementadas pela Secretaria Municipal de Educação por meio do Departamento Pedagógico I. A Deliberação CME 006, 15 de março de 2019, por exemplo, é um dispositivo legal que é parte de esforços coletivos de profissionais da educação para a construção de uma educação antirracista na cidade de Magé.
} 


\section{RevistAleph}

Ariès $^{76}$ (1973) é considerado o pioneiro quando se pensa a história da infância. Segundo Seabra e Sousa (2013), Ariès faz parte de um movimento chamado Nova História, onde a infância começa a ser traduzida como uma construção social. Esse movimento também produz novos olhares sobre os métodos e as linguagens da historiografia, favorecendo apropriações múltiplas para a escrita das histórias, como pinturas, fotos, diários e outros artefatos.

Mas, por que discorrer sobre um pensador francês que narrou uma infância única, de uma específica realidade europeia, você deve estar se perguntando. Porque, como já sinalizado anteriormente, Philippe Ariès, é quem anuncia o sentimento de infância na transição da Idade Média para a Modernidade. Ou seja, a infância passa a ser entendida como construção social, desde os escritos de Ariès.

Não obstante, já no final do século XX, quase três décadas após o postulado de Ariès, uma urgência que se colocava: "Crianças estão merecendo estudos como crianças", disse Corsaro (1997, p.95). Era o surgimento do que chamamos de Sociologia da Infância, onde os estudos da infância são legitimados como campo científico (SARMENTO, 2005). Diversos e diferentes são os pesquisadores, partindo da Europa, que nos anos 90 se dedicaram a pensar as crianças como sujeitos ativos e criativos, capazes de criar culturas: as suas próprias e as do mundo adulto.

E se, como William Corsaro, concordamos que a infância é parte da sociedade, somos convidados a agir taticamente por caminhos metodológicos que amplifiquem suas vozes, para que junto delas, criemos "artes de fazer" instituindo um novo mundo, a partir de sua própria realidade.

Somos provocados também a refletir sobre a legitimidade e complexidade da criança, não mais sobre suas vozes invisíveis. Mas com as suas vozes que bradam e expressam saberes, dialogando com as diferentes áreas do conhecimento: história, sociologia, psicologia, filosofia, antropologia, tecnológica e tantas outras. Segundo Pereira (2016, p.28), pensar a

\footnotetext{
${ }^{76}$ Autor da produção historiográfica: A Consagrado pela obra: História Social da Criança e da Família na década de 60. Ariès (1978). Ariès, descreveu a infância europeia a partir do século XII, explicitando o sentimento sobre a infância, seu comportamento nas relações sociais e na família. Apesar da grande contribuição no campo da Infância, sua obra sofreu críticas por retratar uma única realidade, a europeia. Desconsiderando as outras infâncias, sobretudo as crianças pobres e de classes populares.
} 


\section{RevistAleph}

criança a partir do entrelaçamento dessas ciências é conferir-lhe status de um ser social complexo e em devir.

Nesse caminho, onde a criança é um entrelaçamento de ciências, saberes e histórias, a pesquisa etnográfica foi ganhando forma. Segundo Kramer (2002), essa alternativa garante procedimentos metodológicos e estratégias favoráveis às interações adulto e criança (p. 44).

Manuel Sarmento (2011), pesquisador português das Infâncias, disserta sobre à etnografia na educação. Para o autor,

[...] etnografia visa apreender a vida, tal qual ela é quotidianamente conduzida, simbolizada e interpretada pelos actores sociais nos seus contextos de aç̧ão. Ora, a vida é, por definição, plural nas suas manifestações, imprevisível no seu desenvolvimento, expressa não apenas nas palavras mas também nas linguagens dos gestos e das formas, ambígua nos seus significados e múltipla nas direcções e sentidos por que se desdobra e percorre (p. 17).

Outro caminho metodológico adotado, e que converge com a etnografia, foram os Projetos de Trabalho (HERNANDEZ, 1998). Essa metodologia permite a construção de alternativas coletivas, reflexivas e interativas com diferentes saberes, que por vezes estão silenciados no cotidiano.

A professora desta narrativa, entendeu que a organização do currículo por Projetos de Trabalho, tratava-se de uma maneira de fortalecer os protagonismos dos atores daquele cotidiano, evidenciando seus desejos, suas potencialidades, suas dúvidas, percepções sobre si e sobre o mundo. Além de mobilizar a aprendizagem de maneira prazerosa.

Por exemplo, aprender sobre números romanos, pode ser envolvente se dialogados com outros componentes curriculares que não sejam a matemática e sua linguagem técnica. Porque não mesclar a Arte, a Filosofia e a História da África para provocar a curiosidade dos alunos e positivar as relações étnico-raciais?

Pesquisar sobre a biografia de mulheres feministas e perceber a influência das mulheres negras que exerceram protagonismos na sociedade brasileira, pode ser inspirador. Principalmente para as meninas negras. Desenhar em tela sua imagem, com uma diversidade de cores e traços, é uma forma de demonstrar que suas histórias importam.

Um desafio constante para a realização dos Projetos de Trabalho é a superação da fragmentação do conhecimento pela interdisciplinaridade. A razão de ser desse desafio está na forte cultura conservadora das instituições de ensino, onde algumas, ainda insistem em 


\title{
RevistAleph
}

organizar os alunos na sala de aula sentados em fileiras, onde o professor é tido como detentor do saber e as disciplinas são ensinadas de maneira isolada.

Encontramos em Michel de Certeau (1996), respostas para superar este desafio, visto que sua proposta é inverter perspectivas instituídas com criatividade e táticas, nesse campo estratégico que é a escola. Vale ressaltar aqui, que as ferramentas para enfrentar esse desafio foram variadas: registros em caderno de campo, produção biográficas, exibição de audiovisual, utilização de recursos tecnológicos e digitais.

Muitos foram os saberes, os modos e os artefatos envolvidos para a reinvenção do cotidiano. E reconhecemos que essa reinvenção, só foi possível no tempo da experiência e do acontecimento (tempo também da incerteza), como já afirmava Deleuze (KOHAN, 2002).

Jorge Larrosa (2011) reforça essa ideia, complementando que a experiência está cada vez mais rara. E considerando que vivemos em um mundo globalizado e com uma crescente nas lógicas técnico-científicas, viver experiências plenas, de construção coletiva de saberes artesanais e de afirmação da diversidade humana, é afirmar as vozes e expressões da Infância enquanto potencializadoras de nossa ação transformadora no mundo. Expressões essas, interpretadas como as artes de fazer dos praticantes do cotidiano que se movem no campo das estratégicas e com imaginação, ludicidade, simbolismo, criatividade e táticas, reavivam a prece: Oh, meu corpo, faça sempre de mim um homem que questiona!

\section{Reinventando o cotidiano com as artes de fazer mediado por histórias que importam}

\begin{abstract}
se a produção e a transmissão do saber, na escola, não forem mediados pela particularidade cultural da população negra, as práticas pedagógicas continuarão punindo as crianças negras que o sistema de ensino não conseguiu ainda excluir, aplicando-lhes o seguinte castigo: reclusão, ritualizada em procedimentos escolares de efeito impeditivo, cujo resultado imediato é o silenciamento da criança negra, a curto prazo, e o do cidadão, para o resto da vida
\end{abstract}

GONÇALVES (1987, p. 29).

Ao afirmar que a criança é produtora de culturas na relação entre pares e também entre adultos, a Sociologia da Infância, rompe com teorias funcionalistas que outrora a identificaram como reprodutora e condicionada às normas da sociedade. William Corsaro 


\title{
RevistAleph
}

(2005), inaugura a categoria conceitual chamada Reprodução Interpretativa, onde defende a capacidade de interpretação e transformação que têm as crianças.

Em outras palavras, a expressão Interpretativa é entendida pela forma inventiva e criativa da criança de participar de suas culturas. Já a expressão reprodução, refere-se à sua capacidade para a reprodução da sociedade ou para a mudança social.

Com esse entendimento, Pereira (2016) nos provoca a realizar as seguintes perguntas: qual é a cultura escolar na qual nossas crianças têm sido formadas? Esse meio tem favorecido o reconhecimento de suas subjetividades a partir de suas diferenças? Esse meio tem provocado a inclusão da diversidade étnico-cultural nos espaços educativos e fora deles? Com as narrativas que seguem, vamos respondendo essas e outras perguntas, que podem também ser a de muitos outros docentes.

\begin{abstract}
...fiz uma breve entrevista com os alunos, a fim de entender qual era a origem da negação de sua etnia. Percebi que as crianças ou suas famílias já tinham sofrido casos de racismo, inclusive dentro da escola. Quando comecei a ouvir os relatos dos alunos, surgiu a necessidade de estudarmos sobre a origem do bairro e da comunidade. Foi quando descobrimos que alguns alunos têm origem em uma comunidade Quilombola, próximo à escola e outros alunos são descendentes de pessoas que foram escravizadas. Estas, logo após a abolição da escravatura, se instalaram no bairro, para o trabalho na lavoura e o campesinato (Registro do caderno de campo. BERMUTE, 2019). ${ }^{77}$
\end{abstract}

O exercício de uma escuta atenta e de observação constantes é fundamental para construir experiências afetivas e com sentido para os discentes e também para nós docentes. Outrora, ouvi dizer que de um óleo quente se faz pipocas. E é justamente a partir da sistematização desses sentidos que foi possível criar estratégias para ampliar as culturas locais e também ressignificá-las.

O óleo quente talvez tenha sido, objetivamente, o fato das crianças não se reconhecerem como negras, terem vergonha de sua cor e sequer saberem que eram oriundas de um território de remanescentes quilombolas ${ }^{78}$. Era visível que tudo isso gerava uma crise de identidade. E foi possível perceber à medida que as crianças se recusavam a pintar seu

\footnotetext{
${ }^{77}$ A partir desses dados, procurei a direção e a equipe pedagógica de unidade escolar para falar sobre a ideia do projeto. Tive o aval para iniciar as ações referentes ao projeto "Construindo Identidades".

${ }^{78}$ A escola M. Tiradentes fica localizada em um bairro vizinho ao bairro de Bongaba (6o Distrito de Magé), onde existe um território de remanescente quilombola e onde alguns alunos da turma vivem.
} 


\section{RevistAleph}

autorretrato com cor diferente. Essas percepções provocaram o aprofundamento da discussão.

Com isso, houve a necessidade de realizar um encontro com os pais e responsáveis para apresentar a ideia do projeto que estava nascendo. Isso implicava em evidenciar para eles diferentes questões, como: sobre as narrativas de seus filhos e filhas, as ideias das crianças, a origem de algumas famílias do bairro e também as atividades que seriam desenvolvidas na escola e na/com a comunidade.

Tudo isso, desdobrou em reflexões a respeito da importância de fortalecer as identidades dos estudantes e assim minimizar os preconceitos latentes na turma e na unidade escolar. Essa interlocução com a comunidade de pais e responsáveis foi positiva e dialógica, pois os mesmos abraçaram a ideia, solicitando que o projeto se estendesse a toda escola.

Sem dúvida, o provérbio africano que diz que é preciso uma aldeia para educar uma criança nunca fez tanto sentido. Nunca fez tanto sentido a cultura de pares e intergeracional (SARMENTO, 2005), na produção de relações étnico-raciais mais saudáveis e acolhedoras.

Assim, com a mediação de diferentes atores no processo educativo, as artes de fazer docentes e discentes vão ganhando potência. Importante salientar que o projeto se constitui de 10 etapas, que foram sendo construídas de acordo com os indícios e as solicitações das crianças. A primeira atividade foi a construção do documento de identidade, onde foi consolidado a escrita do nome (escrita correta do substantivo próprio, filiação).

Logo em seguida foi construída a árvore genealógica, para trabalhar o sobrenome. Outra criação diferente de tudo que os estudantes já tinham feito foi um acróstico com o primeiro nome. Nele, foi pedido para colocar palavras e símbolos que tivessem a ver com a personalidade de cada um.

Ações envolvendo a literatura infantil também fizeram parte das experiências. Tudo começou com o Piquenique Literário Africanidades - nome dado pelos próprios estudantes, desejo dos estudantes que gostariam de, ao menos uma vez, usar o jardim da escola para ler. Ao ar livre, no jardim da escola, vários títulos infantis sobre a temática racial e equidade foram lidos. Esta experiência aconteceu no mês de abril, em memória ao Dia do livro infantil. 


\section{RevistAleph}

Figura 1. Piquenique literário Africanidades

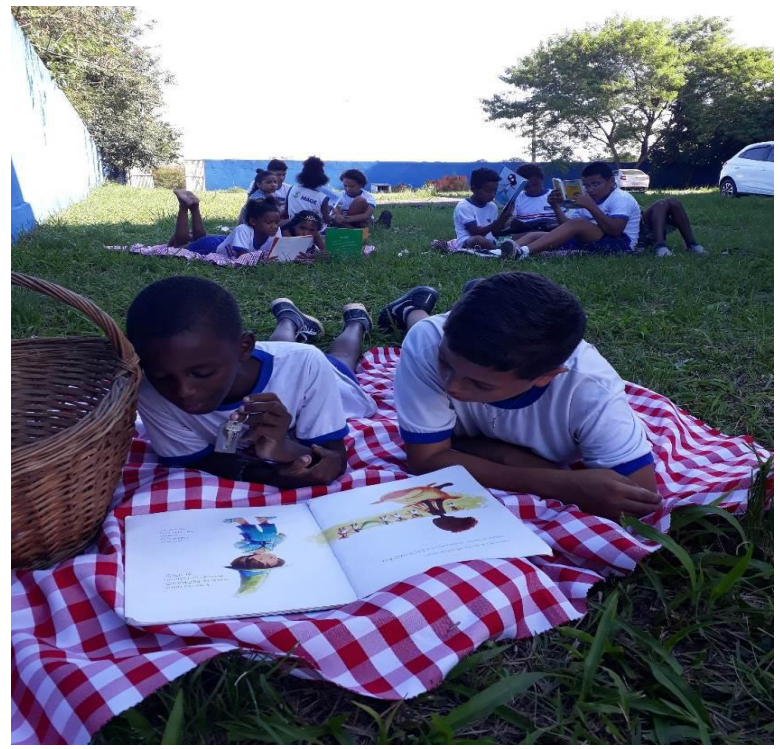

Fonte: Arquivo pessoal das autoras

A experiência inicial envolvendo a literatura foi crescendo conforme os indícios que os estudantes iam apresentando. Assim, surge a "Hora da leitura"79, onde um dos livros adotados foi: Kiese, história de um africano no Brasil ${ }^{80}$, que fala da trajetória de um menino que é capturado, ainda criança, em sua aldeia, na África. E que chegando ao Brasil, passa a ser escravizado e tem a sua juventude e vida adulta vivida nas amarras da escravidão.

A partir da leitura desse livro, foi estabelecido conversas sobre História do BrasilColônia e Matemática, visto que a obra trata da virada do século. Dessa maneira, a linguagem matemática foi adaptada às atividades por meio dos números romanos.

O trabalho com o conteúdo de matemática teve êxito, afinal de contas, muito distante do que muitos pensam, não é o conteúdo ou o tema que chamará a atenção dos estudantes, mas a forma como ele é tratado. Segundo a historiadora Márcia Guerra (2019), quase todo tema pode ser instigador. O que vai mobilizar a turma é o processo de aprender.

E a organização do currículo por Projetos de Trabalho é um caminho para tal, porque, como falado anteriormente, é uma metodologia que vê no estudante um protagonista que

\footnotetext{
79 Paralelo à "Hora da leitura", existia o livro itinerante "O amigo do rei". Cada criança levava para casa, até que toda a turma tivesse lido. Outras obras foram adotadas. Cabe ressaltar que, foram feitos fichamentos de todos os títulos lidos, trabalhando gêneros textuais e sua estrutura, além de trabalhar produção textual, já que os alunos eram estimulados a escrever sua opinião sobre o título lido.

${ }^{80}$ Kiese. História de Um Africano no Brasil (2015). Autor: Ricardo Dreguer. Editora: Moderna.
} 


\section{RevistAleph}

pensa, interage, se interessa, tem dúvidas, que busca, que pesquisa, que se organiza, que constrói e difunde o conhecimento.

Assim, foi possível desconstruir com as crianças, por meio da literatura, a imagem da monarquia brasileira e de uma sociedade que baseou a sua economia e o seu crescimento em um sistema escravista. Essa descoberta foi impactante para todos, pois acreditavam em uma monarquia glamourosa, baseada nos contos de fadas, de princesas, príncipes, reis e rainhas bondosos.

E se por razões históricas e ideológicas, as diferentes linguagens, sobretudo as orais, ficaram secundarizadas na escola. E nosso papel, enquanto praticantes do cotidiano, é fazer emergir essas linguagens e colocá-las a nosso favor.

Nossa sociedade valoriza muito mais a linguagem escrita por ter na história um apelo forte a cultura grafocêntrica. Não obstante, se sabemos que somos herdeiros de povos africanos e afro-brasileiros, vale reconhecer que estes prezam como valor outros modos de expressão, como a oralidade, a musicalidade, a corporeidade, a ludicidade e tantos outros.

Figura 2: Animais da Savana Africana

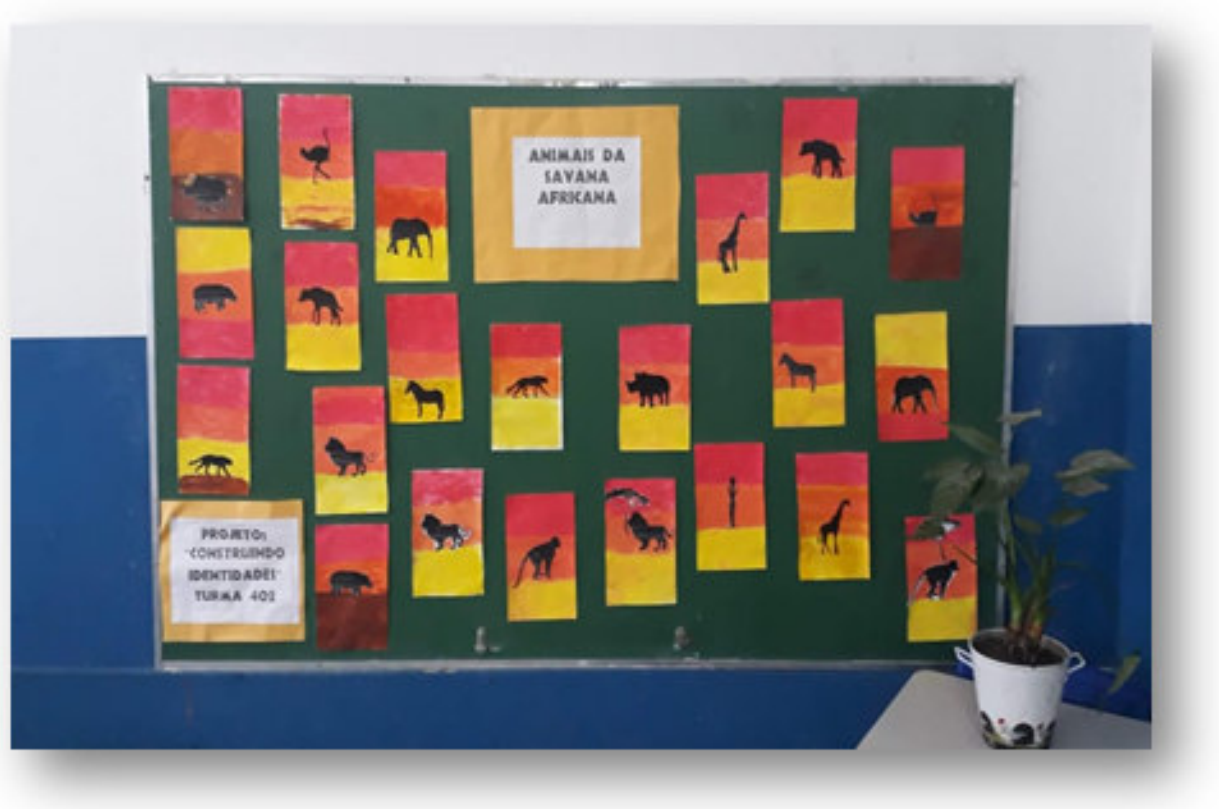

Fonte: Arquivo pessoal das autoras 


\section{RevistAleph}

Assim, os princípios afro-brasileiros (TRINDADE, 2013) da musicalidade, corporeidade e energia vital se fizeram presentes por meio do videoclipe da música África da Palavra Cantada ${ }^{81}$. Entre brincadeiras, danças e cantorias, as crianças sinalizavam na música as palavras, as quais, desconheciam o significado.

As descobertas foram mediadas pela internet e por dicionários. Também foi possível trabalhar encontros vocálicos e interpretação de texto. Além de usar a criatividade na hora de colorir alguns símbolos africanos, como animais da Savana ${ }^{82}$, máscaras africanas, formato do continente Africano. Teve até confecção de colares africanos com papelão e apresentação coreografada na roda africana.

Figura 3: As Artes de fazer dos autores do cotidiano

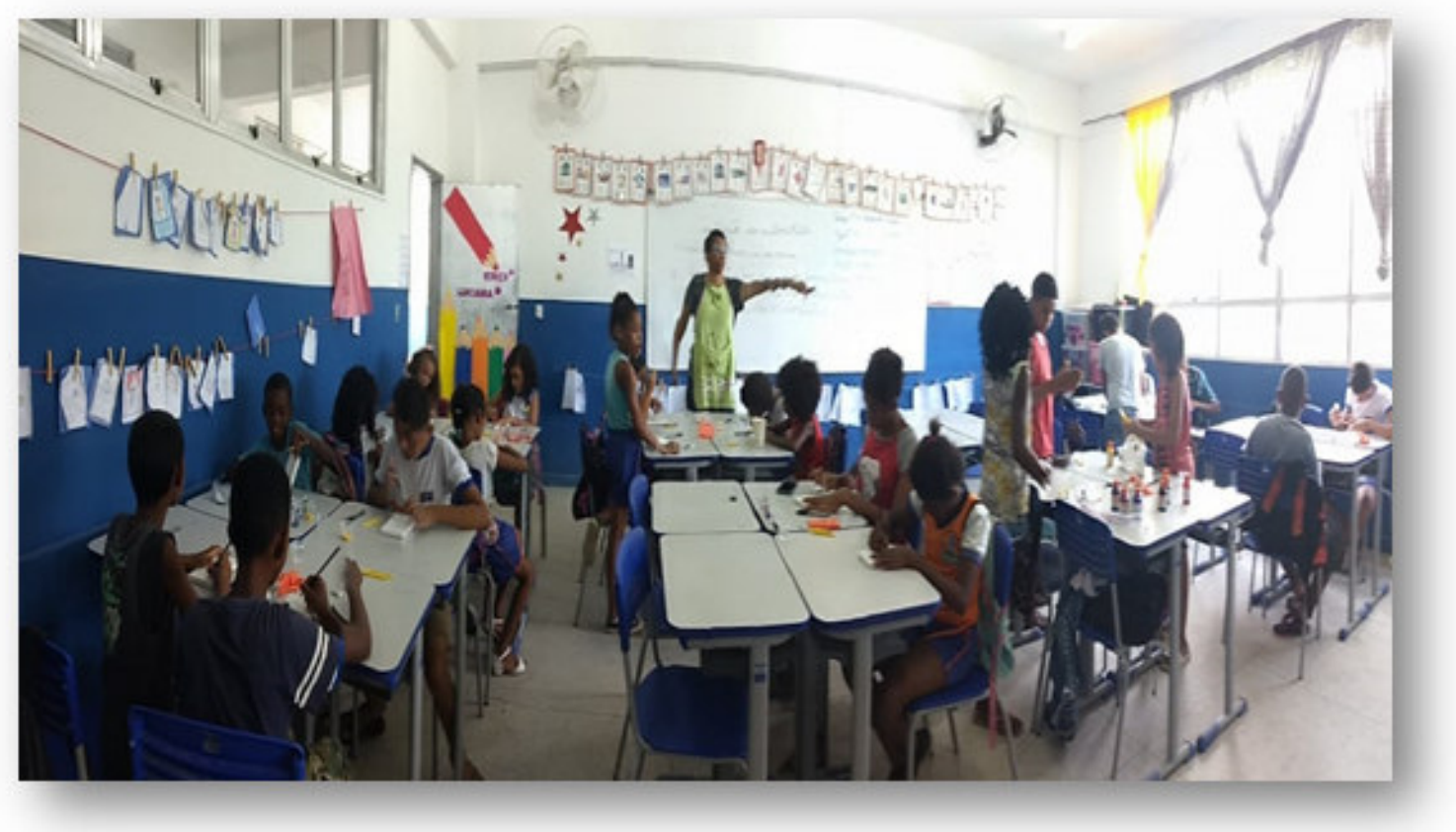

Fonte: Arquivo pessoal das autoras

Outra experiência instituinte envolvendo a música, foi a exibição do videoclipe $A$ carne de Elza Soares ${ }^{83}$, onde os estudantes produziram um texto coletivo sobre racismo e

\footnotetext{
$81 \mathrm{O}$ videoclipe pode ser encontrado no Youtube pelo link:https://www.youtube.com/watch?v=yGv47mv7874

82 Nesse processo, houve discussão sobre animais em extinção e diferentes tipos de biomas. Cada criança escolheu um animal fazendo seu fichamento, nome, habitat e alimentação.

${ }^{83} \mathrm{O}$ videoclipe pode ser encontrado no Youtube pelo link: https://www.youtube.com/watch?v=yktrUMoc1Xw
} (c) (i) (2) 


\section{RevistAleph}

preconceito. O título do texto foi "O racismo no Brasil". Com isso, foram desdobradas atividades envolvendo estrutura de um texto e gêneros textuais.

Em seguida, teve produção acróstico, por sugestão da própria turma, porque gostaram da experiência anterior. A palavra utilizada para o acróstico foi RACISMO. Por meio da música, também foi possível trabalhar a leitura de gráficos, as diferenças entre negros e brancos no que tange ao trabalho infantil, analfabetismo, distorção idade-série, matrículas no ensino superior e vítimas de homicídios. ${ }^{84}$ Cabe ressaltar que as crianças ficaram impactadas com o vídeo e os gráficos, expressando que aquele foi "um dia triste".

Mas reinventar os dias, a partir de nós mesmos, sempre é possível. Afinal, somos herdeiros de homens, mulheres, crianças e idosos que atravessaram o Oceano Atlântico em meio a dores e saudades, mas nem por isso perderam a capacidade de sonhar, cantar, dançar, brincar e refletir.

Figura 4: Telas de Autorretratos em circularidade

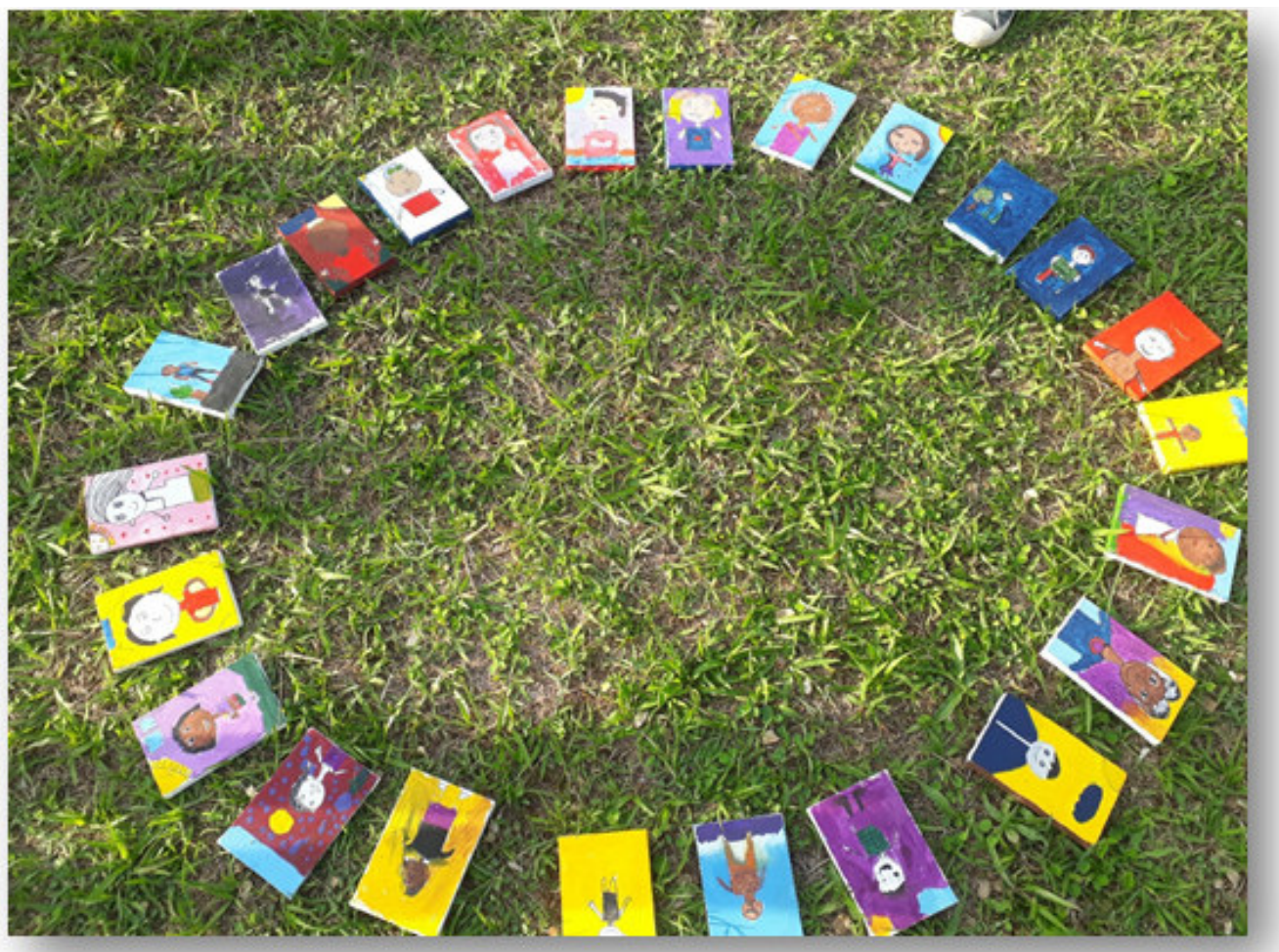

Fonte: Arquivo pessoal das autoras

\footnotetext{
${ }^{84}$ Nesse processo, os estudantes construíram gráficos de mapeamento após coleta de dados sobre a quantidade de negros nas famílias da comunidade escolar que concluíram o ensino Fundamental, médio e superior.
} 
E esse amor guardado em mim Sou bem capaz de uma nuvem tocar

Eu vou seguir muito agradecida

Pelo bom e o ruim dessa vida

E o principal

Sou grata por amar quem eu sou

É que eu sou bonita sim

E estou aqui

Celie (A Cor Púrpura) ${ }^{85}$

Sim, estamos aqui! Meninas, meninos, docentes e comunidade escolar bradando que nossa história importa. Bradamos também que nossa capacidade de sonhar, cantar, dançar, brincar e inventar, resiste! E com táticas continuaremos anunciando o quanto somos bonitos e capazes de reinventar o cotidiano com nossas artes de fazer.

Desse modo, imbuídos de saberes potencializadores de pertencimento étnico-racial, os estudantes construíram seus próprios autorretratos. E se o autorretrato é uma representação que o artista faz de si mesmo, as crianças tiveram a oportunidade de se retratarem enquanto atores inventivos que são ${ }^{86}$.

Por meio das pinturas é possível perceber a desconstrução de identidades dominantes e também de um fetichismo epistêmico (OLIVEIRA; CANDAU, 2010) que despreza outras formas de beleza que não europeias. E essa reflexão não ficou de fora. Com a transposição didática necessária, após a pintura, foi feita uma roda de conversa, bem descontraída, onde as crianças foram provocadas a falar sobre suas criações.

Importante destacar que elas ficaram mais à vontade em misturar as cores e retratar a cor de sua pele como realmente parece ser. Logo, a narrativa inicial "não pinto de preto, porque vão achar feio", não teve espaço nessa experiência diante do prazer e liberdade que vivenciaram. Como diz Larrosa, foram experiências que os atravessaram, e nós completamos: foram experiências que os tornaram livres.

\footnotetext{
85 Trecho do musical A Cor Púrpura da Broadway. A música "I'm Here", na sua versão em português foi interpretada pela artista mageense Letícia Soares, que protagoniza a adorável Celie. A história original foi escrita pela autora, poetisa e feminista negra Alice Walker.

${ }^{86}$ Em uma tela de algodão, usando tinta pva. A partir dessa atividade, foram trabalhadas cores primárias, secundárias e terciárias. Além de texturas, misturas de cores, contorno e sombreamento.
} 


\section{RevistAleph}

Figuras 5 e 6: Pintura em telas
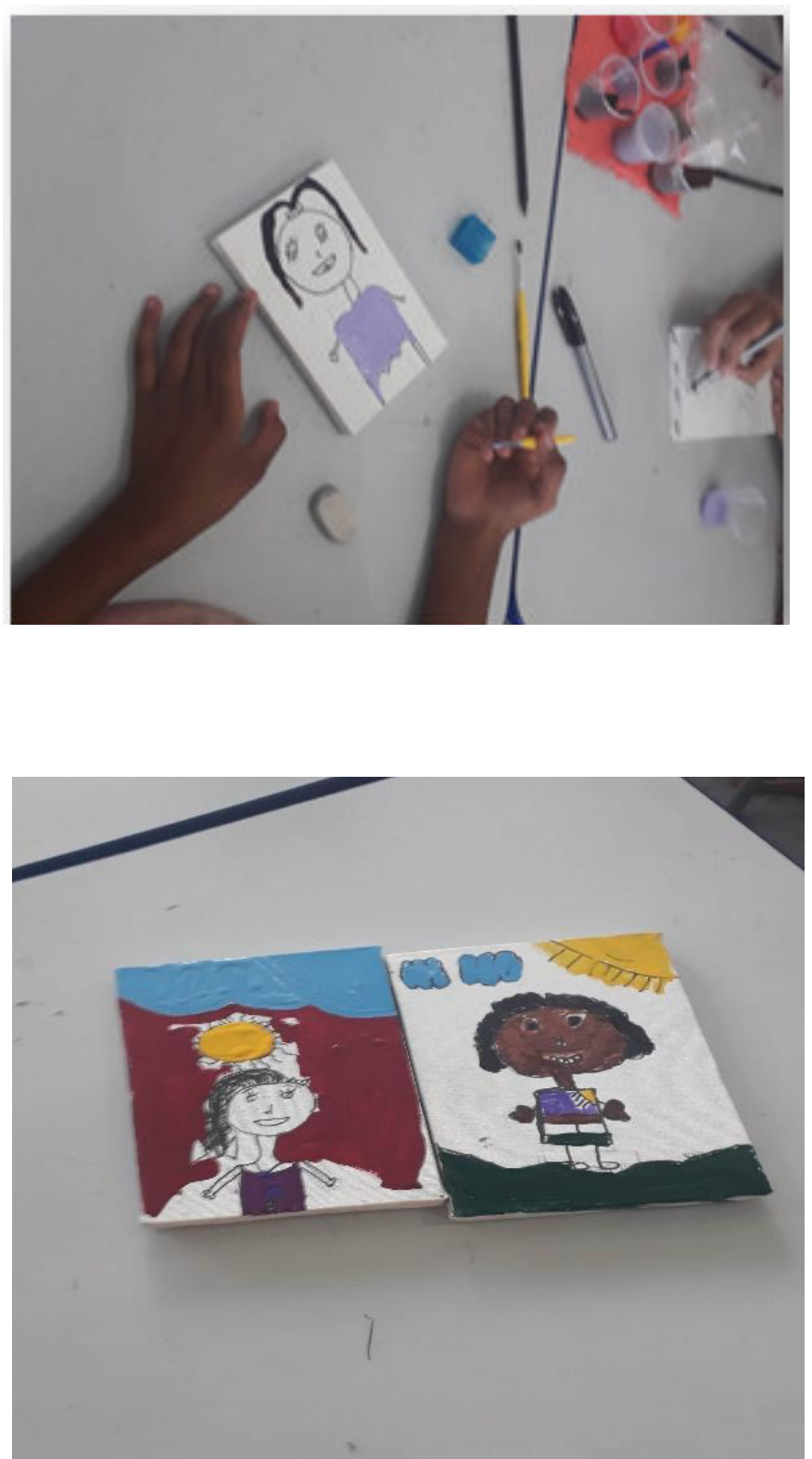

Fonte: Arquivo pessoal das autoras 


\section{RevistAleph}

Figura 7: Pintura de telas da turma

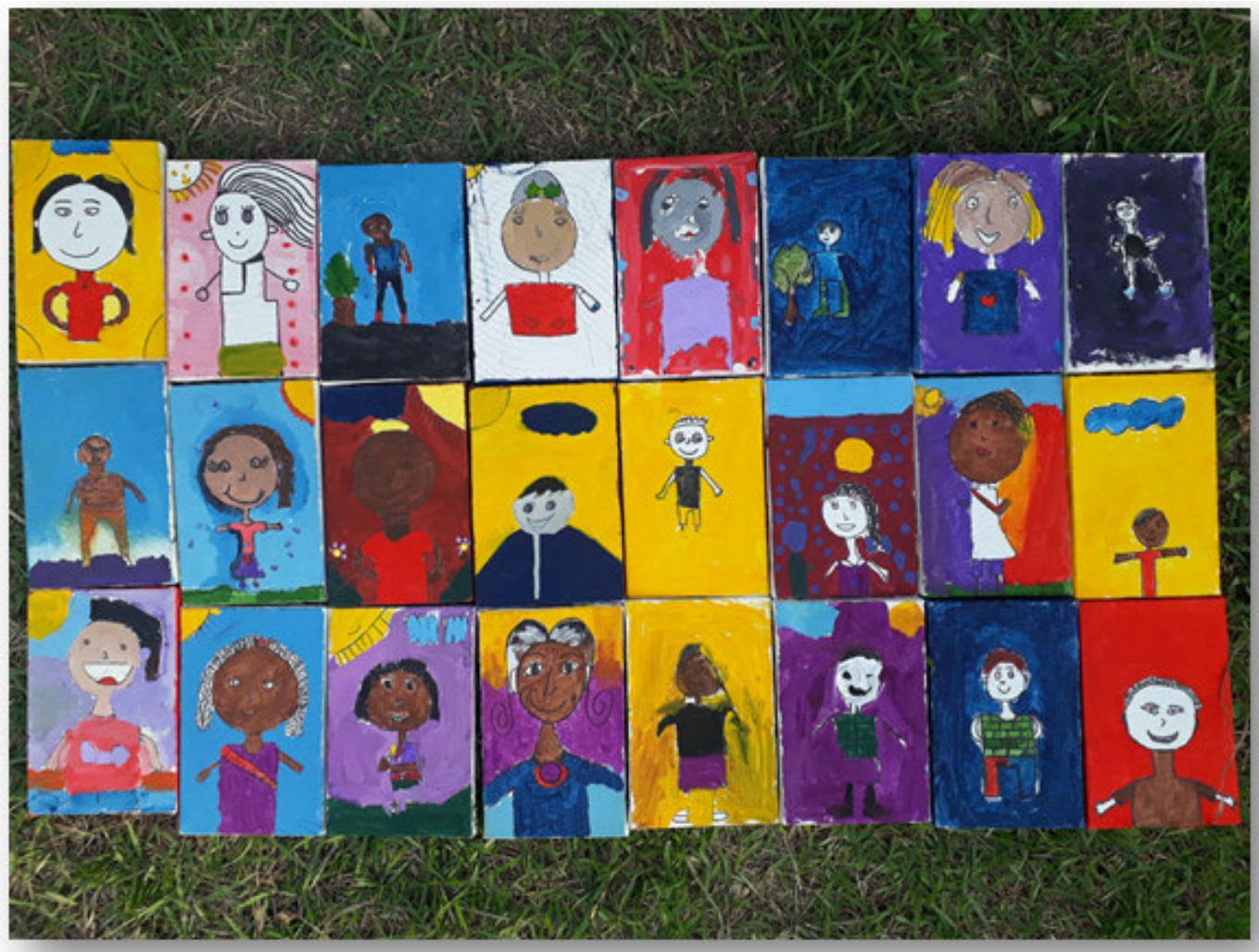

Fonte: Arquivo pessoal das autoras

A atividade de pintura do autorretrato, respondeu a provocação que justificou esse projeto, que era a falta de representatividade negra de uma turma e também o não pertencimento a uma comunidade com tantas histórias bonitas e que por isso, coloridas e dinâmicas. Se essa ação fosse realizada no início, sem percorrer caminhos reflexivos, ativos, interativos e colaborativos, este projeto não se configuraria como uma grande experiência instituinte.

\section{Um encontro precioso com Paulo Freire na ALERJ}

Ensinar exige a convicção de que a mudança é possível.

Paulo Freire (1996)

Paulo Freire, patrono da educação brasileira, sempre soube que a esperança é um ato insurgente, que pequenas resistências constroem liberdades, mesmo que miúdas. No 


\section{RevistAleph}

entanto, para os atores (docente, discentes e comunidade) da escola Municipal Tiradentes, localizada aos Fundos da Baía de Guanabara, essa liberdade era sua maior riqueza.

Pelas mãos da deputada estadual Renata Sousa (PSOL), a professora Kirce Bermute e seus alunos, recebem o 10 Prêmio Paulo Freire da Assembleia Legislativa do Estado do Rio de Janeiro - Alerj na modalidade Experiência Pedagógica no Ensino Fundamental.

Figura 8: 1올 Prêmio Paulo Freire na ALERJ

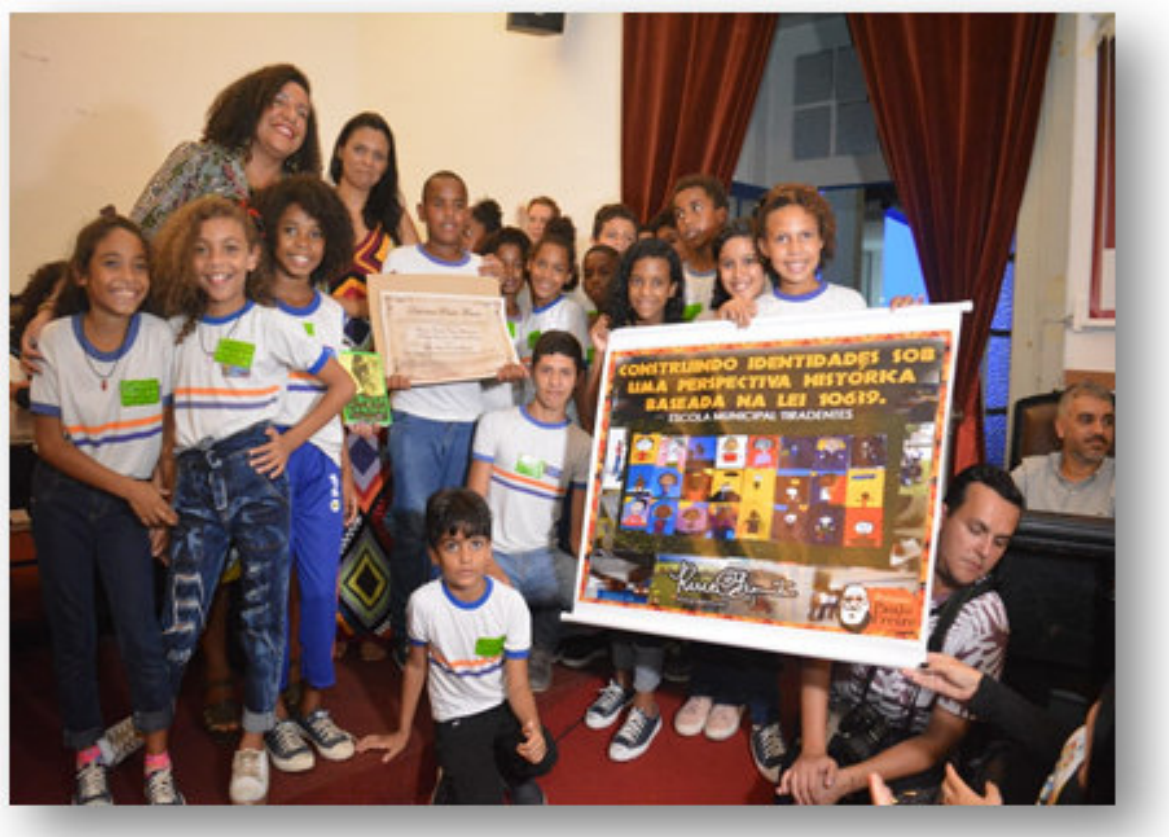

Fonte: Arquivo pessoal das autoras

\section{Caminhando para a conclusão...}

Aprender com o passado, para transformar o presente e mudar o futuro Adinkra Sankofa

Iniciamos este artigo, chamando Frantz Fanon para a conversa. Este autor, com tudo o que representa em sua trajetória acadêmica e militância antirracista, nos inspira. A construção de subjetividades outras no espaço escolar, a partir de uma perspectiva histórica baseada na lei federal 10.639/03, tem muita influência de seu pensamento, já que o mesmo defendia não só uma luta de ideias, mas uma luta prática de reinvenção e libertação do ser humano (PEREIRA, 2019). 
Figura 9: Conhecendo e produzindo Adinkras

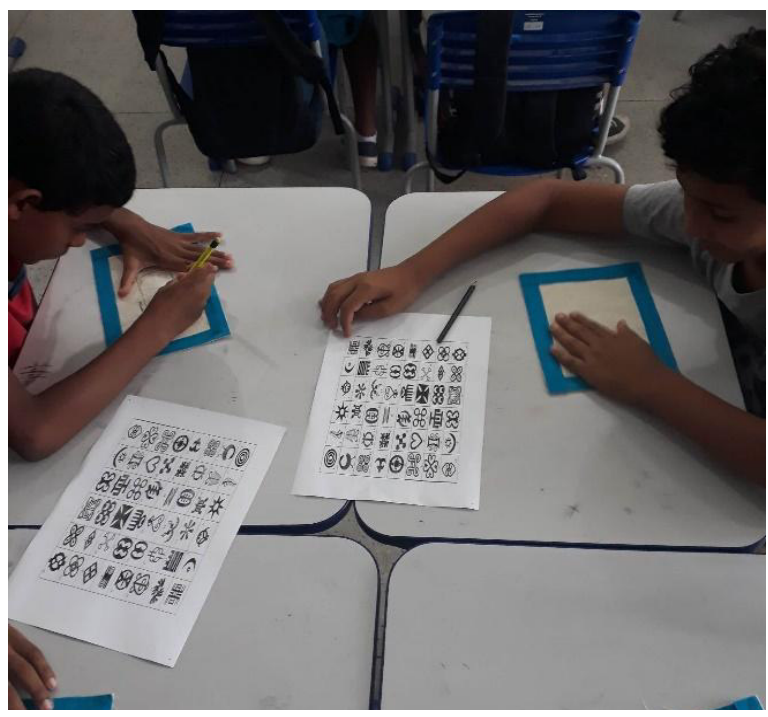

Figura 10: Varal de Adinkras

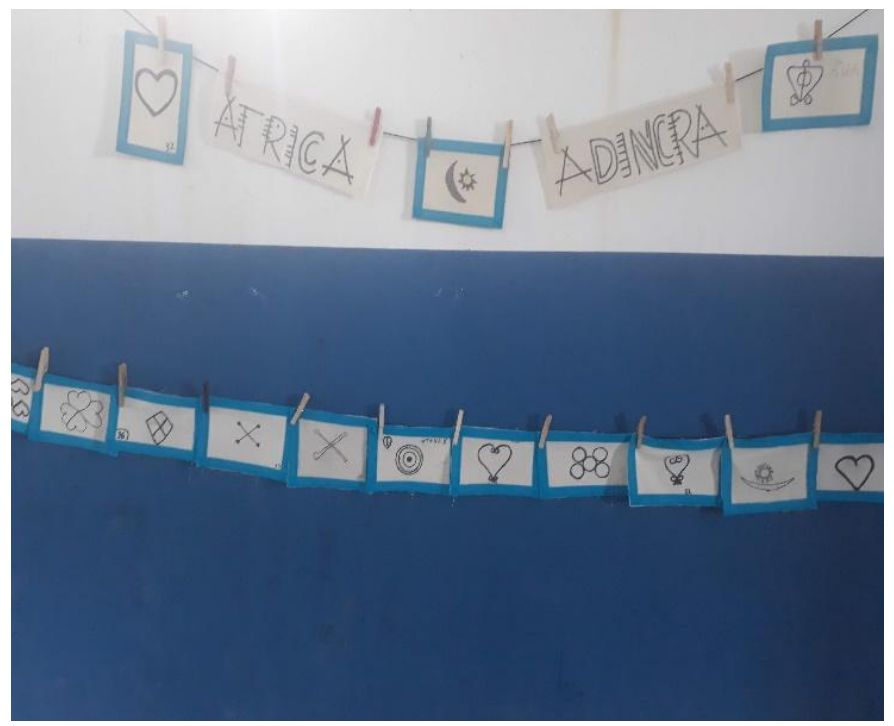

Fonte: Arquivo pessoal das autoras (ambas)

As imagens acima, traduzem essas lutas. Nelas, vemos os símbolos africanos Adinkras, ${ }^{87}$ apropriados e reinventados pelos atores do cotidiano. Estes símbolos representam um sistema de escrita pictográfica e carregam ideias sobre respeito, ancestralidade, sabedoria, crenças e comportamentos. Um Adinkra muito conhecido é o Sankofa (representado por um pássaro olhando para trás). Ele representa o desafio da humanidade de aprender com o passado esquecido e negado, para inaugurar um novo presente e sonhar com um futuro diferente. ${ }^{88}$

E é claro que as crianças entenderam o quanto o projeto Africanidades, iniciado no início do ano letivo, ${ }^{89}$ tinha relação com todos esses símbolos e os saberes que carregam. Assim, cada estudante produziu seu Adinkra, justificou sua escolha e presenteou a família. Essa experiência consolidou a participação da família naquele fim de ano letivo, de modo afetivo e simbólico.

\footnotetext{
${ }^{87}$ Os símbolos Adinkras, faz parte de um sistema de escrita pictográfica, criados pelos povos Akan, presentes em Gana, Costa do Marfim e no Togo, países da África do Oeste.

Fonte: http://www.acaoeducativa.org.br/relacoesraciais/adinkras/

${ }^{88}$ A professora Kirce, autora deste artigo, fez um vídeo falando sobre os Adinkras e os tempos difíceis que estamos passando. Vem ver! Link: https://www.facebook.com/1076138872447298/videos/686627035478774/ 89 O Projeto Africanidades foi o nome dado pelos estudantes ao projeto do Piquenique Literário.foi uma proposta da Secretaria de Educação para o segundo semestre de 2019.
} 


\section{RevistAleph}

Dialogar com a Sociologia da Infância, enquanto campo científico, que concebe a infância como objeto sociológico, foi um caminho que se fez necessário por entendermos que as vozes infantis importam na construção de uma sociedade antirracista.

A continuidade deste trabalho no ano de 2020, se sustentou nos princípios já adotados e também em princípios da etnografia longitudinal (CORSARO, 2005), no sentido de dar continuidade ao processo acompanhamento dos estudantes na transição para o 50 ano do Ensino Fundamental. Segundo Delgado e Muller (2005, p. 171), a etnografia longitudinal é recomendada por William Corsaro como o método ideal para documentar as associações, envolvendo crianças em suas culturas e focalizando os períodos de transição da vida delas.

E como acreditamos que teorias funcionam como lupa para enxergarmos melhor o cotidiano, compartilhamos a seguir flashes das primeiras semanas do ano de 2020. Era o início do mês de março, onde se comemora o Mês da Mulher e também da Luta Internacional pela Eliminação da Discriminação Racial ${ }^{90}$. Foi solicitado aos estudantes uma pesquisa sobre mulheres sobre feministas brasileiras. "Curiosamente" ${ }^{91}$, doze crianças levam biografias de Maria Firmina dos Reis, outras crianças levaram biografias, das mais variadas, não menos importantes que a de Maria Firmina. São elas: Conceição Evaristo e Daiane dos Santos e Maria da Penha. Abaixo, compartilhamos narrativas infantis (palavras e imagens) que expressam os rituais de passagem (com uma nova compreensão sobre identidade negra) não só das crianças, como das culturas escolares (DELGADO e MULLER, 2005, p. 171).

Eu escolhi a Maria Firmina porque ela foi professora. Porque ela é negra. Por isso escolhi ela.

(Narrativa infantil - autora: Geovanna Alves)

Eu escolhi a Maria Firmina dos Reis porque ela escreveu um romance. Ela foi a primeira romancista brasileira. (Narrativa infantil - autor: Bruno Caillon)

${ }^{90}$ As escolas municipais rememoram o Dia 21 de março (Massacre de Shaperville), como um passado que não pode se repetir. Ao longo do mês de março, acontecem ações nas escolas inspiradas na Campanha estadual " 21 Dias de Ativismo Contra o Racismo".

${ }^{91}$ Vale ressaltar que a solicitação foi uma pesquisa sobre mulheres, brasileiras, ativista dos direitos da mulher. (c) (i) (2) 


\section{RevistAleph}

Figura 11: Varal "Mulheres Africanas"

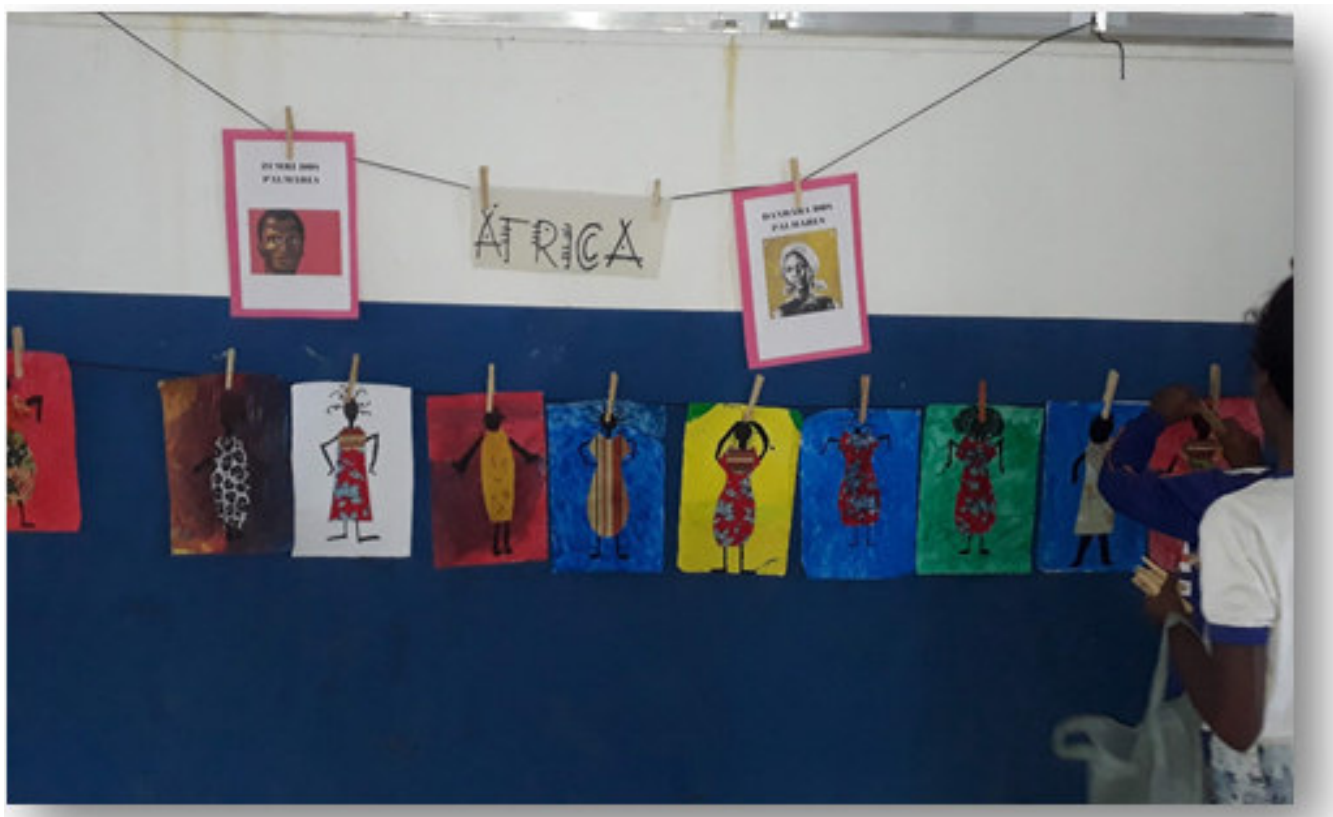

Fonte: Arquivo pessoal das autoras

Figura 12: Avaliação de um dos estudantes sobre o projeto

8 ) Escreva com suas próprias palavias sobre o nosso projeto " Construçăo de Identidade ":

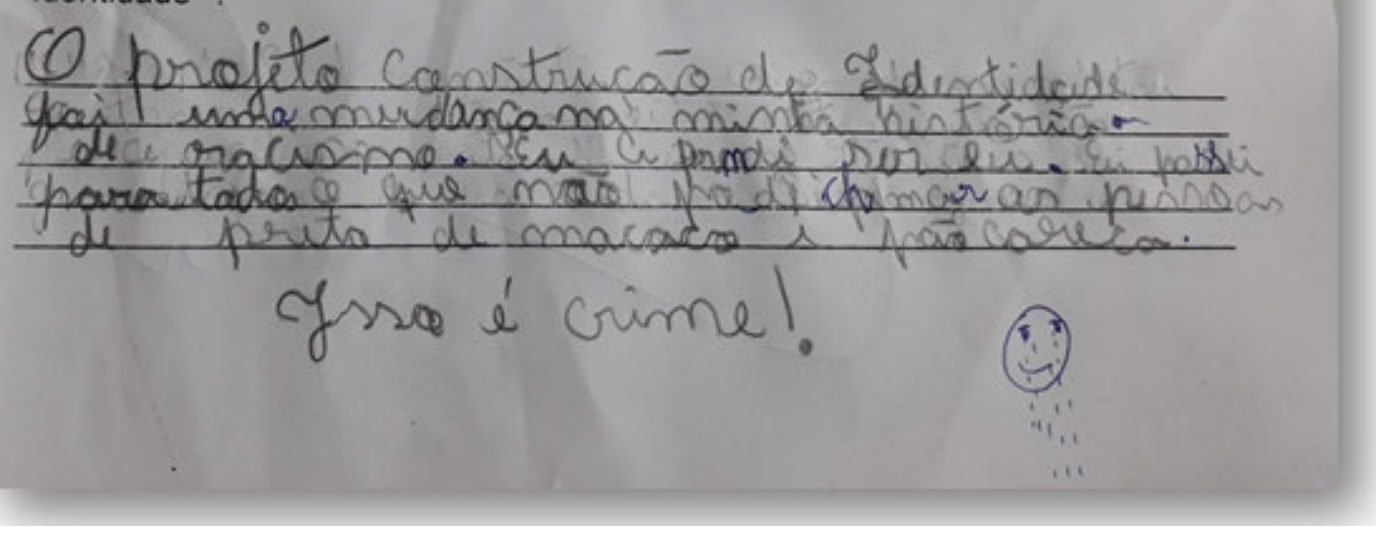

Fonte: Arquivo pessoal das autoras

As ações do projeto, bem como as perspectivas futuras, tornam-se potentes à medida que as parcerias com outros atores e instituições foram sendo construídas, pois desde 


\section{RevistAleph}

o início ficou entendido que a esfera individual é insuficiente. O fortalecimento das redes de apoio será sempre uma tática inteligente dos praticantes do cotidiano.

Assim, uma aproximação com a Universidade foi realizada por meio de um Projeto de Extensão do Curso de Filosofia da Universidade Federal do Rio de Janeiro (UFRJ/IFCS) ${ }^{92}$. 0 grupo Rodas de Filosofia e Transculturalismo teve como objetivo inicial gerar suporte epistêmico e reflexivo para os professores da unidade escolar. Posteriormente, a proposta buscou alcançar o público infantil com oficinas envolvendo os valores afro-brasileiros já mencionados aqui.

Esses movimentos foram e têm sido muito importantes para todos: estudantes, professores, profissionais da escola e comunidade escolar. Importante porque o desejo dos pais e responsáveis estava sendo alcançado - lembra que eles desejaram que as ações do projeto alcançassem toda a escola?

Importante para as crianças que se reconheceram enquanto autoras de histórias reais e também se perceberam lindas nas suas diferentes maneiras de ser e estar no mundo.

Importante para os docentes da escola que estão sendo alcançados com lógicas mais inclusivas da diversidade. E tendo a oportunidade de refletir e dialogar sobre uma educação antirracista em seus percursos formativos ${ }^{93}$.

É importante para a professora que ousou com suas táticas e junto de seus atores, romper com a solidão que muitos docentes enfrentam quando assumem a responsabilidade de lutar contra o racismo estrutural por meio de sua prática educativa.

Na verdade, todos nós ganhamos. Porque os sentidos do fundamento tradicional africano Ubuntu (Eu sou porque nós somos), se fizeram presentes em cada experiência, por meio de uma ética, onde a solidariedade e diálogo foram constantes. Por isso, dedicamos essa escrita às nossas crianças, às crianças pretas e da periferia. A esse momento de resistência e encontros com as táticas dos praticantes da escola Tiradentes, nós dedicamos a todas as crianças que tiveram suas vidas interrompidas pela violência de um Estado genocida. Por isso, bradamos: Vidas Negras Importam! Todas as Vidas Importam!

\footnotetext{
92 Essa aproximação foi por meio dos diálogos que a professora autora realizava com o grupo, visto que este fez parte de seus caminhos de formação enquanto filósofa formada pela UFRJ.

93 Por meio de um projeto institucional junto a Secretaria de Educação de Magé, representado pela COPIED (Departamento Pedagógico I), o grupo Rodas de Filosofia, coordenado pelo professor Fernando Santoro e Marli Azevedo tem ampliado as interações com os docentes, para além das oficinas com as crianças, neste ano de 2020.
} 


\section{Referências}

BERMUTE, K. C. Notas de Campo. Arquivo pessoal. 2019.

BRASIL. Lei no 9.394. Brasília, 20 de dezembro de 1996. Disponível em: https://www.planalto.gov.br/ccivil_03/Leis/L9394.htm .

BRASIL. Lei no 10.639. Brasília, 9 de janeiro de 2003. Disponível em: http://www.planalto.gov.br/ccivil_03/leis/2003/L10.639.htm. Acesso em: 20 de março de 2020.

BRASIL. Diretrizes Curriculares Nacionais para a Educação das Relações Étnico-Raciais e para o Ensino de História e Cultura Afro-Brasileira e Africana. Brasília: MEC/ SEF, 2004.

BITTENCOURT, M. Michel de Certeau 25 anos depois: atualidade de suas contribuições para um olhar sobre a criatividade dos consumidores. Revista Polêmica. v. 11, n. 2 (2012). Disponível em: https://www.e-publicacoes.uerj.br/index.php/polemica/issue/view/245. Acesso em: 20 de março de 2020.

CERTEAU, M. de. A Invenção do cotidiano. Artes de fazer. Petrópolis, Vozes, 1996.

CORSARO, W. The Sociology of childhood. Califórnia: Pine Forge, 1997.

CORSARO, W.A. Entrada no campo, aceitação e natureza da participação nos estudos etnográficos com crianças pequenas. Educação \& Sociedade, Campinas, v. 26, n. 91, p. 443- 464, maio-ago. 2005.

DELGADO, A. C. C.; MULLER, F.. Em busca de metodologias investigativas com crianças e suas culturas. Cadernos de Pesquisa, São Paulo, v. 35, n. 125, p. 161-179, maio/ago. 2005.

EDWARS, C. GANDINI, L. FORMAN, G. As cem linguagens da criança: a abordagem de Reggio Emilia na educação da primeira infância. Porto Alegre: Artmed, 1999.

FANON, F.. Pele negra, máscaras brancas. Tradução de Renato da Silveira. Salvador: 1983.

FREIRE, P.. Educação como prática da liberdade. 23ạ ed. Rio de Janeiro: Paz e Terra, 1999.

FREIRE, P.. Pedagogia da autonomia: saberes necessários à prática educativa. 25. ed. São Paulo: Paz e Terra, 1996.

GONÇALVES, L. A. O.. Reflexão sobre a particularidade cultural na educação das crianças negras. Cadernos de Pesquisa, São Paulo, n. 63, p. 27-29, nov. 1987.

GUERRA, M.. Como provocar o gosto por aprender? Material de divulgação das editoras Ática, Saraiva e Scipione. E-docente: 2019. Disponível em: https://www.edocente.com.br/como-provocaro-gosto-por-aprender-marcia-guerra/. Acessado em: 14/04/2020.

HERNANDEZ, F.. Transgressão e mudança na educação: Projetos de trabalho. Porta Alegre: ArtMed, 1998.

INSTITUTO BRASILEIRO DE GEOGRAFIA E ESTATÍSTICA (IBGE). Dados gerais do município de Magé. 2019. Disponível em: https://cidades.ibge.gov.br/brasil/rj/mage. Acesso em: 29/03/2020. 


\section{RevistAleph}

KOHAN, W.. Entre Deleuze e a Educação: notas para uma política do pensamento. Revista Educação \& Realidade. v. 27, n. 2 (2002) Disponível em: https://www.seer.ufrgs.br/educacaoerealidade/article/view/25922. Acessado em: 14/04/2020.

KRAMER, S.. Autoria e autorização: questões éticas nas pesquisas com crianças. Cadernos de Pesquisa, São Paulo, n. 116, p. 41-59, 2002. Disponível em:

https://www.scielo.br/pdf/cp/n116/14398.pdf. Acessado em: 14/04/2020.

LARROSA, J.. Experiência e alteridade em educação. Revista Reflexão e Ação, Santa Cruz do Sul/SC, v. 19, n. 2, p. 04-27, 2011.

MATURANA, H. e VARELA, F. A árvore do conhecimento: As bases biológicas do entendimento humano. Campinas/SP: Editorial Psy II, 2007.

MOREIRA, R. DOMINICK, R. COARACY, L. CRUZ, L. A Aleph em revista: uma estrada eletrônica. V CEDUCE. 28 a 30 de Junho de 2018. Anais:

http://www.editorarealize.com.br/revistas/ceduce/trabalhos/TRABALHO_EV111_MD1_SA2_ID1329 _03062018175520.pdf. Acesso em 29/03/2020.

NASCIMENTO, A.. Oitenta anos de Abolição. Rio de Janeiro: Cadernos Brasileiros, 1968.

OLIVEIRA, L. F. de.; CANDAU, V. M. F.. Pedagogia decolonial e educação antirracista e intercultural no Brasil. Educ. rev. [online]. 2010, vol.26, n.1, pp.15-40. ISSN 0102-4698. Disponível em: https://doi.org/10.1590/S0102-46982010000100002. Acesso em: 20 de março de 2020.

OLIVEIRA, I.; SGARBI, P. A invenção cotidiana da pesquisa e seus métodos. Educ. Soc., Campinas, vol. 28, n. 98, p. 15-22, jan./abr. 2007. Disponível em:

http://www.scielo.br/pdf/es/v28n98/a02v2898.pdf. Acessado em 12/04/2020.

PEREIRA, S. D.. A Questão Étnico-racial a partir do meu olhar sobre o olhar da criança: promovendo experiências instituintes. Rio de Janeiro: Editora Autografia, 2018.

PEREIRA, S. D.. A Questão Étnico-racial a partir do olhar da criança: a inclusão da diversidade por meio de experiências escolares instituintes. Dissertação de Mestrado: 2016. Disponível em: http://cmpdi.uff.br/2016-2/. Acessado em: 13/04/2020.

PEREIRA, S. D.. A Questão Étnico-racial, perspectivas teóricas críticas e processos educativos em diálogo. Revista Novamerica. № 165 * jan-mar/2020. Disponível em:

http://www.novamerica.org.br/ong/?p=1503. Acessado em 14/04/2020.

SAMPAIO, A. C. J.. Magé na Crise do Escravismo. Sistema Agrário e Evolução Econômica na Produção de Alimentos (1850-1888) Dissertação de Mestrado: 1994. Disponível em:

https://www.historia.uff.br/academico/media/aluno/538/projeto/Dissert-antonio-carlos-juca-desampaio.pdf. Acessado em: 13/05/2020.

SANTOS, B. de S.. Se Deus fosse um ativista dos direitos humanos. Cortez, São Paulo: 2013.

SARMENTO, M. J.. Gerações e alteridade: interrogações a partir da sociologia da infância. Educação \& Sociedade, Campinas, vol. 26, n. 91, p. 361-378, Maio/Ago. 2005. Disponível em:

http://www.cedes.unicamp.br. 


\section{RevistAleph}

SARMENTO, M. J. "O Estudo de Caso Etnográfico em Educação" In N. Zago; M. Pinto de Carvalho; R. A. T. Vilela (Org.) Itinerários de Pesquisa - Perspectivas Qualitativas em Sociologia da Educação (137 - 179). Rio de Janeiro: Lamparina (2a edição), 2011.

TRINDADE, A. L. (org.) Africanidades brasileiras e educação [livro eletrônico]: Salto para o Futuro. Rio de Janeiro: ACERP; Brasília: TV Escola, 2013.

Data do envio: $15 / 04 / 2020$

Data do aceite: 01/07/2020. 